\title{
The Political Significance of Gifts of Power in the Khmer and Mercian Kingdoms 793-926
}

\section{Dominic Goodall and Andrew Wareham*}

This paper compares four Latin charters and one recently discovered Sanskrit inscription recording various royal gifts of taxation to religious foundations in the contemporary Mercian and Khmer kingdoms in the early ninth and early tenth centuries. It draws upon philology and medieval history as its principal disciplines, and considers three models of gift-giving as a way of interpreting the data. Close textual investigation of these records is used to challenge narratives which suggest that such gifts of power weakened the power of rulers, and thus led to the breakup of states. It is equally possible to argue that these gifts of power enhanced the power of Mercian and Khmer kings. Moreover, other powerful factors, such as a cultural renaissance or environmental crisis, may be adduced to explain the context for the compilation of these documents, thereby opening up new perspectives for enquiry into the history of the Khmer and Mercian kingdoms in the early medieval period.

Keywords: Cambodia; charters; gifts; Hwicce; immunities; inscriptions; Khmer; Laos; Latin; Mercia; military; Saivism; Sanskrit; taxation; Vat Phu

The comparison of the meanings of gift-giving in Buddhism and Christianity is to be valued as an important contribution to the historical debate on gift-exchange, which, as has been said before, when it explicitly makes use of anthropological models of gift-exchange, only refers to studies of gift-exchange in 'primitive<, illiterate societies and seems erroneously unaware of the ongoing research on religious gift-giving in large-scale, literate traditions such as Buddhism and Hinduism. ${ }^{1}$

* Correspondence details: Dominic Goodall, École française d’Extrême-Orient, 16-19 rue Dumas, 605001 Pondicherry, India. Email: dominic.goodall@efeo-pondicherry.org. Andrew Wareham, Department of Humanities, University of Roehampton, Grove House, London, SW15 5PJ, UK. Email: a.wareham@roehampton.ac.uk.

1 Bijsterveld, Medieval Gift, 143. 
Since the early twentieth century, comparative studies of gift-giving and kingship have shown that in primitive and pre-modern societies, royal gifts of land and power given to religious foundations in return for money and other counter-gifts may have had less to do with purely economic history and more to do with concepts of mutual obligation and the politics of negotiation. ${ }^{2}$ This approach has developed mainly from medievalists' engagement with anthropologists' studies of gift-giving in Africa, Asia and Polynesia in the colonial and post-colonial eras. ${ }^{3}$ This article takes a different approach, and is intended as a step in the direction suggested by Arnoud-Jan Bijsterveld (as stated in the epigraph to this article).

We may start by briefly outlining three models of gift-giving evident in the work of medieval historians:

1. gift-giving and commercial transactions often operated in tandem, and thus many transactions which were presented as gifts and counter-gifts were in fact sales;

2. gift-exchange was used for the forging of alliances and in strategies of unification, with a view to enhancing the political power and social prestige of donors, and hence should not be viewed as evidence of the decline of royal power; and

3. gifts need to be differentiated from inalienable possessions, which, after they have been granted retained something of the distinct identities of their original owners and hence served to enhance their authority and prestige to a greater degree than it served those of the recipients.

Historians of Anglo-Saxon England have tended to favour the first model, ${ }^{4}$ in contrast to historians of Francia, who have pointed to the importance of the second. ${ }^{5}$ The seminal work of Barbara Rosenwein has provided a clear exposition of the second model in showing that the sgenerosity of rulers in the Frankish world served both to proclaim royal power to their subjects and to give them access to local networks of power. ${ }^{6}$ Her argument directly challenged an older school of French historiography, which had argued, in Robert Latouche's words, that the privileges of immunity granted by kings were >degrading concessions « which arose from the sincapacity and dishonesty of royal agents who, as we know [...] were rogues. Never in our history has the conception of the state known so complete an eclipse. ${ }^{7}$ We intend to explore all three models by looking at gifts of power to religious institutions in the Mercian and Khmer kingdoms.

2 E.g. Gurevich, Categories of Medieval Culture, 185, 257-258; Reuter, Property Transactions, 181-183; Samson, Economic Anthropology and the Vikings. There is an extensive literature on gift-giving in other branches of study and it is worth drawing attention to such distinctions as that observed by sinologists between nar (present), used in the case of an exchange between courts of equal standing, and 'hsien (to offer up) tribute ('kungr) in a vertical relationship (Wright, From War to Diplomatic Parity, 216); I am grateful to Annabel Smith for discussion of this point.

3 We have found the following historical studies especially useful: Alghazi et al., Negotiating the Gift; Davies and Fouracre, Languages of the Gift; Heitzman, Gifts of Power; Rosenwein, Negotiating Space.

4 Naismith, Land Market; below, nn. 40, 57-58.

5 E.g. Curta, Merovingian and Carolingian Gift Giving; Nelson, Settings of the Gift; Rosenwein, Francia and Polynesia, 362-366. It is important to note that there are differences between historians who use this model; for doubts on Rosenwein's model, see Curta, Merovingian and Carolingian Gift Giving, esp. 671 n. 3, 698.

6 Rosenwein, Negotiating Space, 14-18, 74-96, 135-177.

7 Latouche, Birth of the Western Economy, 129. 
A further word about what we mean by inalienable possessions may be useful before we begin. In medieval worlds, inalienable possessions, such as monarchs' clothes, saints' relics and holy books, continued to enhance the authority of their original owners and makers while still transferring some sense of royalty and sacrality to the new holders or owners. ${ }^{8}$ But in addition to this type of inalienable possession, the anthropologist Annette Weiner in her seminal study also drew attention to treasures entirely excluded from gift-exchange that were integral to lineages' and institutions' identity and power: sunlike the most famous inalienable Maori, Taonga or Samoan fine mats, the inalienable kula shells do not move back and forth between local lineage and political affairs [...] these possessions symbolize the inalienability of the group and, at the same time, a chief's growing reputation and immortality..$^{9}$ Therefore, some gift-exchange can be used to draw attention to non-circulated goods, emphasising the separation of royalty from society and its over-arching authority over spiritual and secular affairs. ${ }^{10}$

In the following pages, Part I discusses the background and context of four charters in which Mercian kings transferred fiscal rights to monastic foundations in south-west Mercia; Part II sets out the data from recent advances in the discovery and interpretation of Sanskrit inscriptions in the Khmer kingdom; and Part III makes some general observations arising from our comparative approach.

\section{I: Mercian kings and their religious foundations}

The archive of the bishopric of Worcester provides the principle collection of charters for studying the political, social and cultural worlds of the Mercian polity, which dominated Anglo-Saxon England for much of the eighth and ninth centuries. Four charters dealing with fiscal grants to religious foundations in the south-western part of the Mercian kingdom were originally drawn up between 793 and 855, but at the beginning of the eleventh century these and many other Mercian royal charters were copied into the earliest Worcester and indeed earliest English cartulary, the Liber Wigorniensis. ${ }^{11}$ These dates have been chosen for the concentration of fiscal charters, but this period is also one of note for other reasons, standing as it does between the aftermath of the Council of Nicaea (787), and the first reference to the English as an ethnic and political group in the vernacular (855). ${ }^{12}$

The Liber Wigorniensis fulfilled two purposes; first, it was a work of ecclesiastical history, and second, it helped the bishopric and community of Worcester to maintain rights to lands and dues during a period of severe political and economic stress. ${ }^{13}$ The fiscal charters it records were all issued on behalf of Mercian kings, but it is important to remember that these and other early ninth-century Mercian charters do not reflect the perspectives of the

8 Bijsterveld, Medieval Gift, 125; Curta, Merovingian and Carolingian Gift Giving, 694-695; Weiner, Inalienable Possessions, 33-36.

9 Weiner, Inalienable Possessions, esp. 133-148 (quote at p. 145).

10 Weiner, Inalienable Possessions, esp. 133-148; Quigley, Introduction, 3-6.

11 BL MS Cotton Tiberius A.xiii.

12 Gallagher, Vernacular in Anglo-Saxon Charters, at n. 138.

13 Wareham, Redaction of Cartularies; cf. Baxter, Archbishop Wulfstan, 162-163, 172-175; Tinti, Sustaining Belief, 85-92, 120-125. 
Mercian royal court in the manner that West Saxon charters produced in the 840 s do for the West Saxon royal house. ${ }^{14}$ Nonetheless, we should not necessarily assume that the charters reflect an ecclesiastical advance in which the bishopric sought to gain power and prestige at the expense of royal and secular power. We cannot fully understand the cultural milieu of the production of early ninth-century Mercian charters because so much information is missing. ${ }^{15}$ But by restricting our discussion to a select group of charters concerned with fiscal immunities over two generations, it may be possible to reach some conclusions about the political significance of these gifts of power.

The Liber Wigorniensis was concerned with the history of the bishopric of Worcester mainly within its regional hinterland of south-west Mercia, known as Hwicce. The name Hwicce, first mentioned c. $603 \mathrm{CE}$, perhaps referred to a people of British origin who lived in a chest- or ark-like landscape (a possible etymology of the kingdom's name) in the lowland area of the Severn and Avon valleys, bounded by the watersheds of the Cotswold, Lickey and Malvern hills (over 200 feet) and the woodlands of the Arden and Wyre forests. ${ }^{16}$ The land was well drained with naturally fertile soils lying close to the Avon, Severn and Teme rivers, and the economic resource of the salt wells at Droitwich (Worcs.) was one of the four marvels of Britain referred to in Nennius' early ninth-century Historia Brittonum. ${ }^{17}$ The region stood on the western fringe of the English cultural zone that comprised most of southern and eastern Britain, which in turn may have developed from even more ancient divisions between the eastern and southern regions and the northern and western regions of the island. ${ }^{18}$ Between c. 601 and c. 610 there reportedly took place a meeting between Augustine, archbishop of Canterbury, and a group of British bishops, perhaps on the borders of the kingdom in southern Gloucestershire. ${ }^{19}$ The location of this meeting sunder an oak tree could provide further evidence for an important connection between Irish monasticism and British Christianity long before the authority of Canterbury and the Roman Catholic church was established among the Hwicce in the late seventh century. ${ }^{20}$ The former Roman city of Gloucester, lying on the crossing over the river Severn of the road linking London with south Wales, was the strategic centre of the early kingdom, which may have stretched as far as Bath (Somerset) and included much of Herefordshire. ${ }^{21}$

The Hwiccian dynasty had English origins and kinship connections with the Bernician royal dynasty (in Northumbria), but its political ties of subordination were with the Mercian kings, whose power was focused around the central and north-east midlands of England. ${ }^{22}$

15 For an excellent survey and important conclusions, see Gallagher, Vernacular in Anglo-Saxon Charters.

16 Hooke, Anglo-Saxon Landscape, 3-21; Coates, Name of the Hwicce.

17 Hooke, Droitwich Salt Industry; Zaluckyj, Mercia, 110; Nennius, Historia Brittonum, ed. Morris, $40,81$.

18 Cox, Church and Vale of Evesham, 29-30; Reynolds, Early Medieval Period, 143-146.

19 Bede, Ecclesiastical History II.2, ed. McClure and Collins, 71-74; Cubitt, Anglo-Saxon Church Councils, $207-208$.

20 Bede, Ecclesiastical History III.4, ed. McClure and Collins, 115 on the foundation of Columba (fl. 521-597) at Dearmarch sthe field of oaks leading to the establishment of many monasteries in Britain; for discussion of early Christianity in western England, see Sims-Williams, Religion and Literature in Western England, 73-86.

21 Clarke, Economy, 62; Yorke, Kings and Kingdoms, 13, 108-109.

22 For the view that smaller and medium sized kingdoms within Mercia were created as subsidiary states of the Mercian kings, see Zalcukyj, Mercia, 103. 
The kingdom acted as a buffer state for the Mercians in dealing with the Welsh and West Saxon kingdoms, but the kings of the Hwicce were not recorded in histories and chronicles as great warrior kings. ${ }^{23}$ Their prestige and authority was enhanced by their deference to the dignity and authority of the Mercian rulers, who also acted as patrons of the Hwiccian church, thereby creating a multi-centred and multi-layered network of political power within the kingdom. ${ }^{24}$ By the late seventh century, the Hwiccian kingdom, shorn of its lands in Herefordshire, was assessed at 7,000 hides. The hide, a standard unit for measuring wealth in Anglo-Saxon England, resists precise definition in this period, but these figures make Hwicce a medium-sized Anglo-Saxon kingdom, stretching over Gloucestershire, Worcestershire and south-western Warwickshire. ${ }^{25}$ Beneath the level of the kingdom there were a number of smaller territories (regiones), such as the Woeogran, which gave its name to Worcester, the Usmere connected to an ecclesiastical centre (or minster) at Kidderminster, and the Wixan associated with minsters at Inkberrow and Fladbury. ${ }^{26}$ Between c. 778 and c. 800 the Hwiccian kings disappeared from the historical sources, with power being delegated by Mercian kings to ealdormen, but charters and other sources continued to refer to lands in Gloucestershire, Worcestershire and south-western Warwickshire as lying within the territory of the Hwicce well into the late Anglo-Saxon and Anglo-Norman periods. ${ }^{27}$

Before turning to the four charters on which this section focuses, and which are concerned with the churches or minsters at Westbury, Hanbury, Bredon and Blockley, it is helpful to consider some of the possible patterns of gift-giving in transfers of land in the Hwiccian kingdom between the 690 s and 840 s, to give a sense of context. In 706 Æthelweard (fl. 693-c. 717), ruler of the Hwicce, with the consent of the Mercian king, granted 12 hides at Ombersley (Worcs.) to Evesham abbey, freeing the land from all public taxes and royal dues, though the king reserved his rights to pannage for the royal swine from an island in the river Severn. ${ }^{28}$ There was no counter-gift of treasure or land, but Æthelweard did expect the monks of Evesham to pray for his soul and for that of Ecgwine, bishop of Worcester and abbot of Evesham. ${ }^{29}$ This charter points to the significance of the alliance between secular and ecclesiastical power; the king did not insist upon the payment of the three common military burdens (of army service, fortress and bridge work) in the grant, because the charter pre-dated the emergence of these obligations in England.

23 On different forms of early medieval kingship, see James, Origins of the Barbarian Kingdoms, 43-46. Perhaps kings of the Hwicce were among the 30 sub-kings (duces regii) who fought on the Mercian side at the battle of the Winwæd in 655 (on the campaign and its administrative significance, see Yorke, Kings and Kingdoms, 105).

24 Brooks, Formation of the Mercian Kingdom, 59, 163-164; Chadwick, Studies in Anglo-Saxon Institutions, 281-282; Campbell, Bede's Reges and Principes, 91-92; Yorke, Nunneries and Royal Houses, 197-198 (in particular see the entry on Hanbury); eadem, Kings and Kingdoms, 105; cf. Bassett, In Search of the Origins, 6-20. For a useful comparison, see Schnepel, Kings and Tribes in East India, 200-201.

25 Bassett, In Search of the Origins, 6; Yorke, Kings and Kingdoms, 10-13; cf. Chadwick, Studies on Anglo-Saxon Institutions, 280-282.

26 Bassett, In Search of the Origins, 18-19; Hooke, Anglo-Saxon Landscape, 75-84. This region has provided some key evidence for the minster hypothesis, which suggests that monastic communities undertook pastoral duties in their hinterlands (regiones) until the ninth-century crisis and the emergence of the parochial system in the tenth and eleventh centuries (see Blair, Church in Anglo-Saxon Society, 291-367).

27 S 215 (B 540); Cox, Church and Vale of Evesham, 177; Hooke, Anglo-Saxon Landscape, 20.

28 S 54 (B 116) commented upon by Clarke, Economy, 62.

29 On Ecgwine's career, Cox, Church and Vale of Evesham, 4-35. 
Between 704 and 709 Æthelheard and Æthelweard as joint rulers of the Hwicce granted five hides at Ington (Warwicks.) to Cuthswith in exchange for 600 shillings, and she gave the land to the nunnery at Inkberrow (Worcs.). ${ }^{30}$ This charter demonstrated the wealth of Cuthswith in undertaking a property-buying transaction, ${ }^{31}$ but raises the question of whether 600 shillings was a fair price for her to pay for just five hides. Cuthswith was a kinswoman of an ealdorman who had served King Oshere (fl. 680-93), father of Æthelheard and Æthelweard, and joint ruler of the Hwicce with his brother Osric. ${ }^{32}$ When Æthelheard and Æthelweard granted land to Cuthswith they may have sought to establish a connection both with her family and with the Wixan via Inkberrow. The counter-gift may have symbolized mutual recognition between the rulers of the Hwicce and Cuthswith, in line with the second model of gift-giving. ${ }^{33}$

For the early medieval period, it is difficult to separate the different aspects of price in terms of the costs of entering the market and meeting the conditions prevailing within it from the economic value and opportunities of the goods and lands transferred. In a charter dated to 849 , which survives only as a copy in the Liber Wigorniensis, it was recorded that in the midst of the Viking onslaught, Berhtwulf, king of Mercia (840-c. 852), leased five hides at Cofton Hackett for five lives to a thegn named Ecgberht, who in return gave the king $£ 60$ in pure gold and silver. ${ }^{34}$ Cofton Hackett lay on the northern boundary of the Hwiccian kingdom and perhaps comprised the core of a 20-hide estate..$^{35}$ Cofton Hackett was rich in woodland, and had a dairy farm and industrial buildings. ${ }^{36}$ But paying $£ 12$ per hide for five lives, even with these assets, was probably a poor economic deal for Ecgbert, and perhaps his generous counter-gift was intended to act as a signpost of deference towards King Berhtwulf. In the preceding charter in the Liber Wigorniensis cartulary, also dated to 849, 20 hides, including the five hides at Cofton Hackett, had been leased by Ealhhun, bishop of Worcester, to King Berhtwulf for five lives sfor our defence and in order that sthe king be more firmly the friend of the bishop and his community ${ }^{37}$ Ecgberht was probably close to both Berhtwulf and Ealhhun, and he may have wanted to achieve several objectives in purchasing the Cofton Hackett lease ${ }^{38}$ First, it enabled Ecgberht to show his friendship towards the king; second, it protected the interests of the bishopric in ensuring that a friend had an interest over part of the 20-hide holding leased to the king; and third, it may have helped the king to raise funds for the war against the Vikings. Ecgberht may have played an important role as an intermediary between King Berhtwulf and Bishop Ealhhun, and the price for the lease of Cofton Hackett may have reflected the social and political nature of the transaction.

30 The charter is a seventeenth-century copy: S 1177 (B 122); S 53 (B 85) sets out her connections with their father Oshere in founding a nunnery. Sims-Williams, Religion and Literature in Western England, 191, provides helpful commentary.

31 Sims-Williams, Religion and Literature in Western England, 191-192; PASE Cuthswith 3.

32 Sims-Williams, Religion and Literature in Western England, 191-192; Zaluckyj, Mercia, 105.

33 Such an argument is strengthened by Cuthswith's connections with Carolingian Europe: see Sims-Williams, Religion and Literature in Western England, 191-197, 239.

34 S 199 (B 455). On hidage, see Tinti, Sustaining Belief, 95; Hooke, Worcestershire Anglo-Saxon Charter Bounds, 140.

35 Hooke, Worcestershire Anglo-Saxon Charter Bounds, 140-141.

36 Hooke, Worcestershire Anglo-Saxon Charter Bounds, 138, 141 drawing upon S 1272 (B 455).

37 S 1272 (B 455).

38 In PASE Ecgberht 15 is not linked to any persons of the same name, but it is notable that Ecgberht 16, a priest, witnessed S 1272. 
Before concluding that these three charters provide evidence in favour of the second model of gift-giving, it is worth pausing to consider the text of the charter which leased the land to Ecgberht. It referred to sthis aforementioned land (hanc prenominatum terram), without specifying either its name or its hidage. It has been assumed that this refers back to Cofton Hackett on the grounds that the prose section of the preceding charter ended with an itinerary in the vernacular of the boundaries of Cofton Hackett. ${ }^{39}$ But the raforementioned land c could refer to the whole block of 20 hides identified at the beginning of Bishop Ealhhun's charter in favour of King Berhtwulf, rather than the land described in its vernacular boundary clause. Moreover, the charter in favour of Ecgberht also mentions an important counter-gift. The king freed the land from all secular burdens demanded by kings and ealdormen, but at the boundary of the estate a portion of $\$ 200$ " was to be rendered. It is unclear what this counter-gift was, but sixty pounds may well have been a fair price to pay for holding 20 hides for five lifetimes (i.e. for up to a century and half), in which the holder had the right to collect dues on his estate with some of these payable at the boundary to the king's agents, with the guarantee of the king's protection. Aquinas' famous dictum stantum valet quantum vendi potest, sed communiter may well have applied to this exchange, as well to other similar market-based transactions involving land and treasure in ninth-century England..$^{40}$ But it is also possible that participants used these exchanges to signal varying levels of friendship and coolness both to audiences present at the time and to those who heard (or read about) these transactions at a later date, for purposes disconnected from economic opportunities. These three charters identify the range of choices in interpreting royal gifts of power, and raise possibilities in relation to the first and second models of interpreting gift-giving, but so far provide little evidence in support of the third model.

Charters can easily take second place to the sAnglo-Saxon Chronicle in understanding Anglo-Saxon history. Under the year 829 the >Anglo-Saxon Chronicler recorded: >And that year King Egberht [of Wessex] conquered the kingdom of the Mercians, and everything south of the Humber; and he was the eighth king who was bretwaldar. ${ }^{41}$ The entry suggests that around 829 Mercian power was dealt a hard blow by which Wiglaf, king of Mercia (827-29 \& 830-40) was driven from his throne, with this moment acting as a watershed in the struggle for power between Wessex and Mercia. ${ }^{42}$ The demise of the Hwiccian royal dynasty at the turn of the ninth century can be viewed as part of a prelude to the decline of Mercian royal power. ${ }^{43}$ This is not the place to discuss the role of the bretwalda, the rise and fall of Mercia, or the prosopographical research on the heirs and successors of the Hwiccian royal dynasty, ${ }^{44}$ but we should at least note in passing that the Anglo-Saxon Chronicle was copied

39 www.esawyer.org.uk/charter/199.html; retrieved on 27 November 2017); Hooke, Worcestershire Anglo-Saxon Charter Bounds, 140; Tinti, Sustaining Belief, 95-96; the boundary clause is at BL MS Cotton Tiberius A. xiii, fol. 4r.

40 >A thing is worth as much as it can be commonly sold for cited in Roncaglia, Wealth of Ideas, 40. For markets in England between the ninth and eleventh centuries, see Faith, Structure of the Market, 697; Jones, Transaction Costs, 658; Naismith, Payments for Land, 294.

41 Trans. Whitelock, English Historical Documents, no. 1 at 186.

42 Higham and Ryan, Anglo-Saxon World, 241-242; Wormald, Ninth Century, 139; cf. Keynes, England, 40-41.

43 On the diminishing role of Hwiccian kings c. 778-90, Hooke, Anglo-Saxon Landscape, 19-20; Yorke, Kings and Kingdoms, 113; S 113 (B 223); S 126 (B 233).

44 On the bretwaldas and Mercian power, see Keynes, England, 39-41; for possible descendants of the Hwiccian kings, see PASE Uhtred 2, Uhtred 4 and Uhtred 6. 
in its extant form around c. 890 at the court of Alfred, king of Wessex (870-99), and hence provides a narrative history of earlier centuries from a later, West Saxon and court-centred viewpoint..$^{45}$ The entry for 829 helps to provide a key insight into the history of Mercia in the early ninth century, but it should not be preferred over the evidence of ninth-century charters copied at Worcester cathedral and other religious institutions in the Anglo-Saxon period. It is to four of these charters that this article now turns.

Between 793 and 796 Offa, king of Mercia (757-796), transferred fiscal rights to the bishop of Worcester from lands attached to the minster at Westbury-on-Trym (Gloucs.), also referred to as Westminster, and so named either because it stood to the west of the nunnery at Bath or was located on the western edge of the Hwiccian kingdom..$^{46}$ In the charter, the bishop received freedom from great and small tributes relating to 60 hides at Westbury and 10 (or 20) hides in the adjoining estate of Henbury. These lands had allegedly been held by Offa's grandfather, and in return for the gift he received assistance with the salvation of his own soul, the souls of his parents, and of his son Ecgfrith (d. 796). The charter was witnessed by members of Offa's family, the archbishop of Canterbury, the bishops of Worcester and Leicester, together with a princeps, eight ealdormen and four abbots, thus demonstrating the importance of the occasion. By this date one might have expected Offa to have reserved the three common military burdens, but he chose only to reserve from the Westbury estate a series of food renders, including ale, cheese, corn, oxen and sheep, which formed only a small fraction of the total yield from the estate. ${ }^{47}$ The Westbury food renders broadly matched both the food renders owed to the king from 10 hides in the late seventh-century sLaws of Iner and a mid-ninthcentury render from the minster at Kempsey (Worcs.) to Ealhhun, bishop of Worcester. ${ }^{4}$ Perhaps the Westbury food renders were customary royal dues owed from a small section of the Westbury estate, whose payment served to demonstrate monastic acknowledgement of the authority of the donor. ${ }^{49}$ The purpose of the gift may have been to signal deference by the bishop of Worcester and the Westbury community to Offa as their ruler and protector.

Another of Offa's charters, also issued between 793 and 796, was also concerned with the lands attached to Westbury. Offa granted his thegn Æthelmund 55 hides, which were freed from all great and small tributes, in return for the salvation of Offa's soul. But in this charter Offa reserved the three common military burdens: expedionibus causis et pontium structionum et arcium munimentum quod omni populo necesse est ab eo opera nullum excusatum esser..$^{50}$ The grant was witnessed by the archbishop of Canterbury, eleven bishops and four abbots at the council of Clofesho..$^{51}$ Three interpretations of these two charters issued at and around the time of the synod of Clofesho are possible. One option is to regard one of the documents as a forgery. ${ }^{52} \mathrm{~A}$ second is to assume that Offa changed his mind over whether to

45 Yorke, Kings and Kingdoms, 127-129.

46 S 146 (B 273). For comment on authority of the charter, below, appendix I. On the early history of the minster, Orme and Cannon, Westbury-on-Trym, 7-10.

47 Dyer, Lords and Peasants, 29.

48 Dyer, Lords and Peasants, 28-9; Sims-Williams, Religion and Literature in Western England, 137 n. 5; for further comment on food renders, Faith, English Peasantry, 157.

49 Cf. Dyer, Lords and Peasants, 30.

50 S 139 (B 274): "responsibility for military service and the erecting of bridges and the fortifying of defences because it is necessary for all the people that none are to be excused from this labour."

51 Cubitt, Anglo-Saxon Church Councils, 274.

52 For further discussion and rejection of this view, see appendix I. 
favour Æthelmund or Worcester; and a third, preferred here, is that the two grants were complementary. The charter in favour of Æthelmund not only had a narrower circle of beneficiaries to be mentioned in prayers, but also made no mention of the counter-gift of food renders and only granted freedoms from small and great tributes over 55 hides at Westbury. If these charters complemented each other, the bishop of Worcester had responsibility for providing Offa with annual food renders from a smaller portion of the estate, but it was Æthelmund's responsibility to ensure that the common military burdens were carried out from 55 hides. By the beginning of the eleventh century, these two charters provided materials on the early history of Westbury minster, at that point controlled by Worcester, and hence were copied into the Westbury element of the Liber Wigorniensis..$^{53}$ But in the 790 s these charters may have helped Offa to reorder secular power and his relationship with the church, or at least the writer of the charter was able to present these events in this manner with a degree of plausibility. At a synod at Clofesho in 792, Offa agreed to reduce his rights to dues and services owed from Kentish royal minsters, following the earlier implementation of this policy within Mercia, in exchange for being able to enforce the common military burdens. ${ }^{54}$ In the case of the grant to Westbury, this deal was perhaps accompanied by a separate transaction which signalled the deference of the bishop and monastic community to their royal patron and protector.

In 836, six years after Wiglaf had been restored to the Mercian throne, he granted the minster at Hanbury (Worcs.), in the northern part of the Hwiccian kingdom, freedom from entertaining and supporting the king, ealdormen and frstingmen (agents who carried out a range of duties in the service of Mercian kings). ${ }^{55}$ The community was also freed from great and small tributes that served to maintain a royal residence, perhaps at nearby Wychbold..$^{56}$ In exchange, Wiglaf received absolution from his sins, but he reserved two common military burdens of bridge- and fortress-work. In addition, Heahberht, bishop of Worcester, gave Wiglaf use for one lifetime of three estates from the resources of the bishopric, and further gifts were given to ealdormen, comprising 600 shillings in gold for Ealdorman Sigered and 10 hides for one lifetime to Ealdorman Mucel. The grant was witnessed by the king, the queen, archbishop of Canterbury, 11 bishops from southern England, three abbots, ten ealdormen (including Sigered and two ealdormen named Mucel) and twelve lay followers, with 39 witnesses in all. The events which it recorded were evidently of considerable public significance, and the charter was of signal importance to Patrick Wormald, who used it to argue that:

Mercian kings were not simply alienating their rights and those of their officials: they were selling them for land and treasure. It is a more constructive policy than it looks at first sight, but it could imply that Mercian kings were running short of land [...] the reason why so many Mercian royal charters are grants of privilege rather than land is that their landed resources were drying up, and there was little left with which to endow either the church or their secular followers. ${ }^{57}$

53 BL MS Cotton Tiberius A.xiii, fos. 48-49.

54 Brooks, Development of Military Obligations, 42; Cubitt, Anglo-Saxon Church Councils, 110-113; Yorke, Kings and Kingdoms, 116-117.

55 S 190 (B 416; trans. Whitelock, English Historical Documents, no. 85). For identification of Hanbury as the beneficiary and the role of Bishop Heahberht, see McKinley, Understanding the Earliest Bishops, 96; cf. Bassett, Landed Endowment, 82-84.

56 Hooke, Anglo-Saxon Landscape, 91.

57 Wormald, Ninth Century, 139. The observation was also based upon analysis of S 207 (B 488) discussed below, n. 88. 
The persuasiveness of Wormald's view that this charter documented a sale expressed in the language of gift-giving has been supported and commented upon over the last 25 years by a number of Anglo-Saxon and medieval economic historians, as well as by diplomatists. ${ }^{58}$ This consensus is persuasive but it has perhaps prevented the charter being considered within the framework of the second and third models; and has led to an emphasis on repiscopal greed and opportunism $4 .^{59}$ There are in fact sound grounds for suggesting that the transaction fits the second and third models better, particularly if we give weight not only to the version copied into the Liber Wigorniensis, but also to the original single-sheet diploma, which fortuitously survives as well.
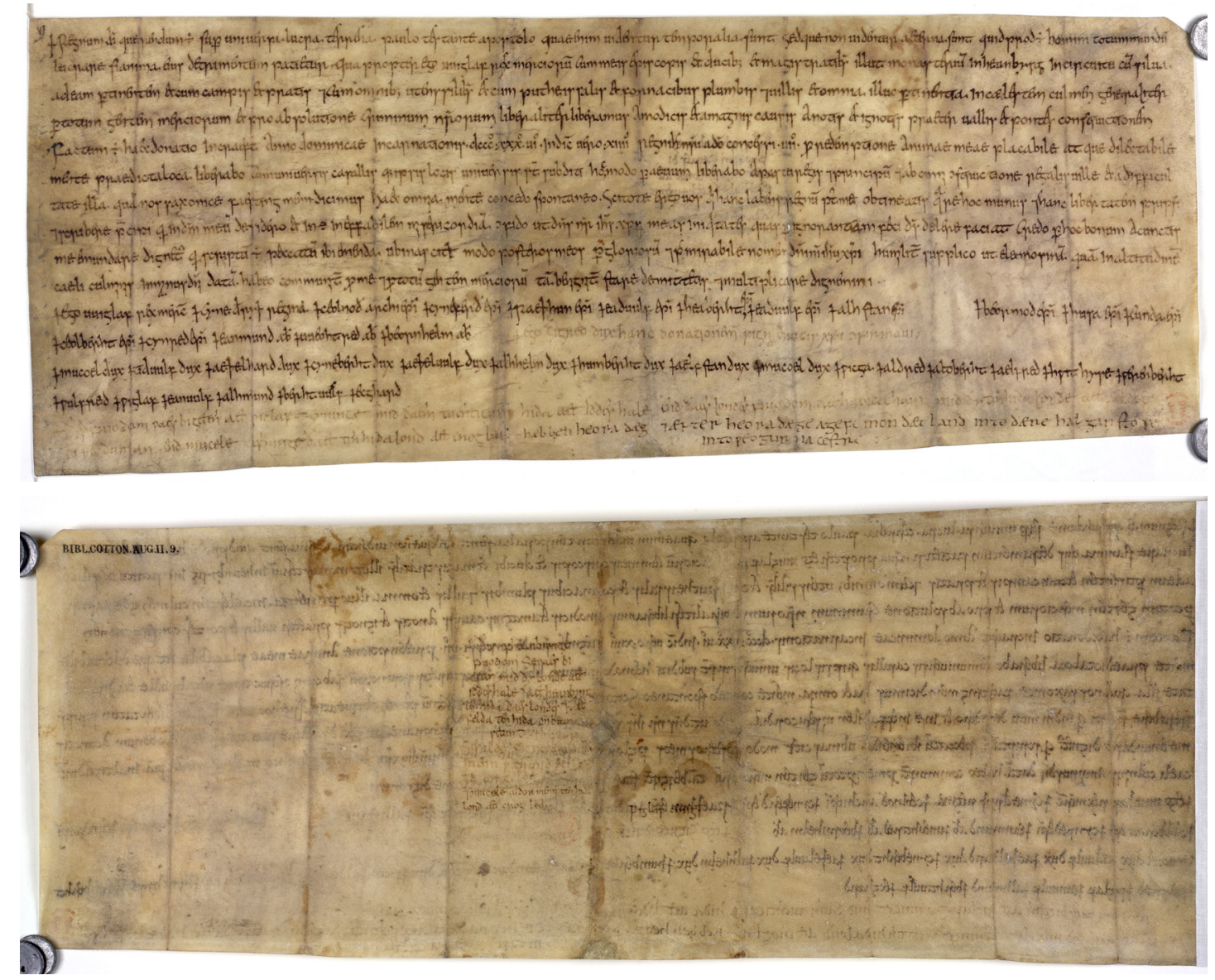

Fig. 1 and 2: British Library, Cotton Ms Augustus II 9, recto and verso

58 E.g. Bassett, Landed Endowment, 83-85; Campbell, Sale of Land, 237; Dyer, Lords and Peasants,16; Higham and Ryan, Anglo-Saxon World, 240; Kelly, Charters of Peterborough Abbey, 210; Yorke, Kings and Kingdoms, 127. Since Wormald's work there has been much discussion of the political and military organization of Mercia. Bassett, Divide and Rule?, esp. 53-54, 84-85 argued for a developed military infrastructure which served as the prototype for the burghal hidage and underpinned the shiring of Mercia; cf. Molyneux, Formation of the English Kingdom.

59 Bassett, Landed Endowment, 85. 
The copy of the text in the Liber Wigorniensis only recorded the grant of the fiscal immunities, omitting the witness list and the details of the counter-gifts. ${ }^{60}$ This charter was appended to the end of the Worcestershire section of the cartulary on folio 21, with two-thirds of the verso left blank. The omission of the witness list and the counter-gifts reduced the value of the text in establishing Worcester's legal rights to Hanbury minster and its estates, but it presented a clearer narrative of an act of royal charity. ${ }^{61}$ The original single diploma measures $490 \mathrm{~mm}$ (width) by $190 \mathrm{~mm}$ (depth), with the grant taking up $120 \mathrm{~mm}$ and with the witness list, written in the same hand, also in Latin, using a further $45 \mathrm{~mm} .{ }^{62}$ The witness list has a line-break after the name of the last ecclesiastic (Abbot Beornhelm), with a new line beginning with the signature of Ealdorman Mucel. A second hand made two additions: first, in the line-break space, after Abbot Beornhelm, we find added in Latin the assertion that "I Sigered, ealdorman, have confirmed this donation with the sign of Christ's cross"; and second, in the remaining $25 \mathrm{~mm}$ at the foot of the charter an endorsement was added in the vernacular which recorded that 30 hides had been given to King Wiglaf, that ten hides had been given to Ealdorman Mucel, and that after their deaths these lands were to revert to the bishopric of Worcester after one life. ${ }^{63}$ The charter has eight fold-marks, and on the dorse in the middle of panel four there is a second endorsement, also written in the vernacular: this repeated the record of the gift of 10 hides to Ealdorman Mucel and the transfer of the other lands, without recording that King Wiglaf was the beneficiary or that any of these lands were to revert to Worcester. This endorsement also recorded that 600 shillings in gold had been given to Ealdorman Sigered. ${ }^{64}$ Finally, in panel five on the dorse the words 'Wiglaf cinig, were written. It seems most likely that both endorsements were added at the same time as the writing of the main text of the charter, but the reference to King Wiglaf is probably a tenth-century addition..$^{65}$ Both endorsements are readily visible, and the separation of information about material counter-gifts, given in the vernacular, from that about non-material gifts in Latin, can be explained as being a result of a typical language choice for presenting different aspects of an exchange. ${ }^{66}$

In order to delve further into the meaning of the original grant it is helpful to turn to the wider diplomatic and landscape context.

60 BL MS Cotton Tiberius A.xiii, fol. 21r-v.

61 For further discussion of fols 20v-21v, see Tinti, Sustaining Belief, 102; Wareham, Redaction of Cartularies, 206207.

62 BL MS Augustus ii. 9.

63 For a hypothesis on the location of all lands recorded in the endorsements, see Bassett, Landed endowment, 8789, 93-4.

64 For the suggestion that this was the purchase price of 600 oxen, see Bassett, Landed endowment, 83 n. 18.

65 Gallagher, Vernacular in Anglo-Saxon Charters, at nn. 85, 91.

66 This is necessarily a speculative point, for as pointed out in Gallagher, Vernacular in Anglo-Saxon Charters, at n. 93, no other ninth-century original single sheet includes such endorsements. 


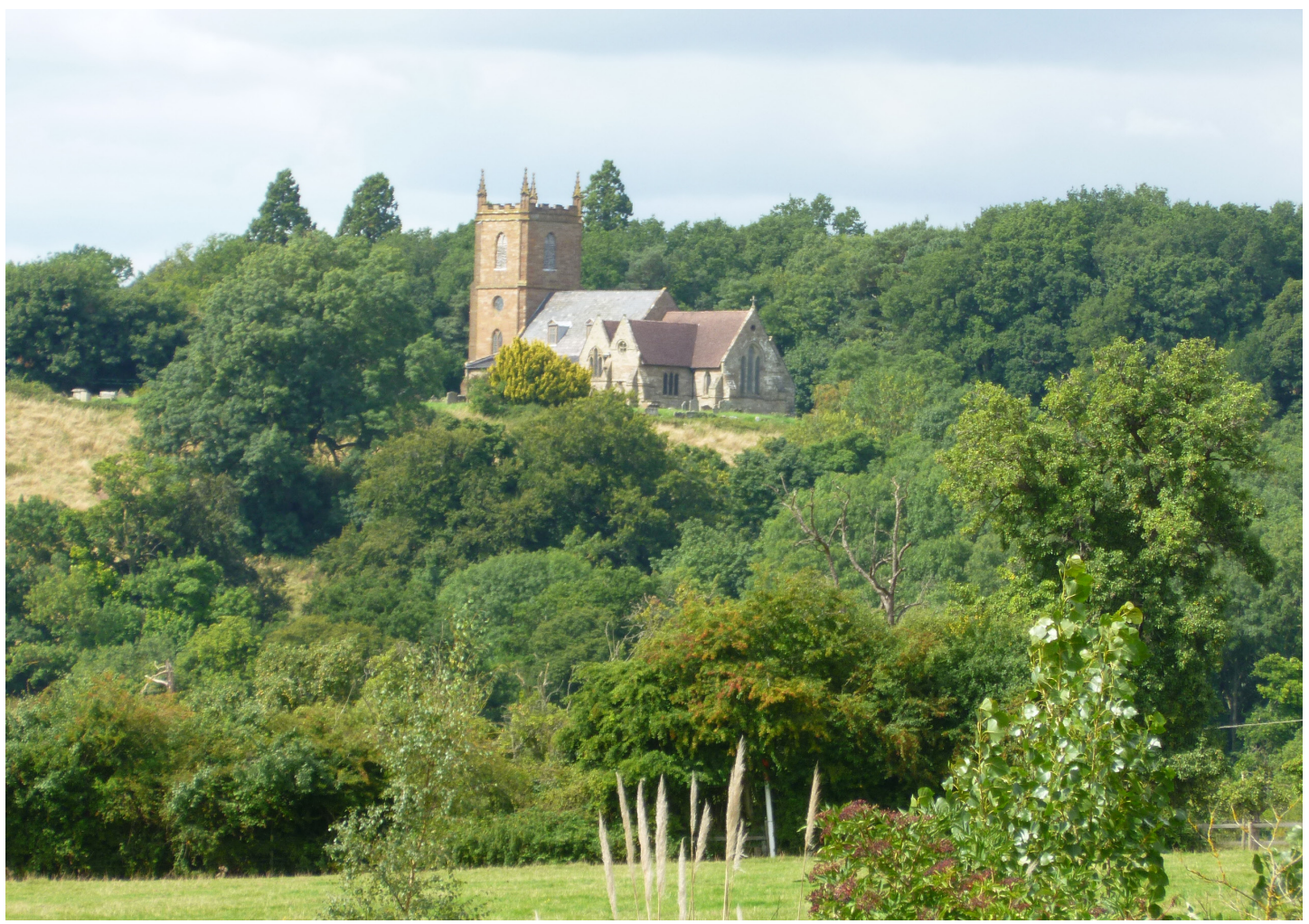

Fig. 3: View of Hanbury minster (photo: Elisabeth Wareham)

At Hanbury, field-walking and place-name evidence have shown that an Iron-Age hill-fort was occupied in the Roman period, and that a small British settlement continued to occupy the site in the early Anglo-Saxon period. ${ }^{67}$ Hanbury minster was adjacent to three important centres of political and economic power, comprising the regio of the Usmere, the royal vill at Wychbold, and the salt-works at Droitwich. ${ }^{68}$ In a charter dated between 657 and 674, Wulfhere, king of Mercia (659-75), granted Abbot Colmán 50 hides at Hanbury, with its meadows, woods and 'wells of salt at Droitwich, demonstrating an important connection between the Mercian royal house and Hanbury minster. ${ }^{69}$ In the view of Patrick Sims-Williams, Colmán's name suggests that he came from Ireland, but a connection with Bernicia and Lindisfarne is also plausible. ${ }^{70}$ Between 757 and 774 Abbot Ceolfrith granted 20 hides at Hanbury from his paternal inheritance to the bishopric of Worcester, suggesting that it was at this stage that the see acquired an interest over the formally independent minster. ${ }^{71}$ Finally, it is worth looking at another of Wiglaf's charters dating from the period after his restoration. Between 829

67 Dyer, Hanbury, 16, 20; Sims-Williams, Religion and Literature in Western England, 107.

68 Hooke, Anglo-Saxon Landscape, 91.

69 S 1822; Sims-Williams, Religion and Literature in Western England, 106-107.

70 Sims-Williams, Religion and Literature in Western England, 107; Hooke, Anglo-Saxon Landscape, 11.

71 S 1411 (B 220); for discussion on authority, appendix I. My argument strengthens Steven Bassett's view that Worcester had acquired a substantial interest over Hanbury minster before the 840 s (see idem, Landed Endowment, 81-87). 
and 836 he recognised Sigeric as king of the East Saxons in a charter in which the bishop of London leased 10 hides in Hertfordshire for one lifetime to Sigeric minister in exchange for a cash payment of 4,000 silver coins. ${ }^{72}$ The transaction was perhaps intended to reconstitute the alliance between the royal houses of Mercia and the East Saxons, following the demise of the kings of Essex as semi-autonomous rulers during the reign of Offa. ${ }^{73}$ Taken together, this wider evidence casts doubt on the view that the Hanbury charter demonstrated that Wiglaf sold his fiscal rights in order to reward ealdormen with lands and money (model one), and encourages us to consider whether the second or third models might be more helpful.

Hanbury minster was an important political and religious centre, and both the kings of Mercia and the bishops of Worcester had connections with it reaching back into the seventh and eighth centuries. In granting these concessions, Wiglaf may have been seeking to refresh this political alliance as part of a unification strategy to bring stability to his rule after his restoration, and the counter-gift of 600 shillings and gifts of land may have been intended as a way of recognizing the importance of this alliance. A hint of this is provided by the fact that in addition to using the anno domini date, the charter also recorded that this was the seventh year of Wiglaf's reign. There was no diplomatic need to add this second date, but its political significance is clear. By noting that 829 marked the beginning of a snew reign, Wiglaf may have aimed to remove from memory both his ejection from the Mercian throne and problems associated with his sfirst reign up to 829. The charter ended with Wiglaf's request that future generations should uphold his alms (eleemonsa), noticeably avoiding the language of the gift (donatio) used earlier in the charter to outline the nature of the fiscal freedoms. No indication was given of the extent of the lands which were to be freed under the terms of the grant. In the Domesday Book Hanbury and three other manors held by the bishop of Worcester in the same hundred, which were managed jointly, had an aggregate hidage of 36 hides. $^{74}$ Only one hide was in demesne on the manor of Hanbury, but the rent from the manor also included 105 measures of salt from Droitwich..$^{75}$ Alternatively, if late medieval and modern evidence can be used to reconstruct the original landed endowment of the minster, as set out by Steven Bassett, then 600 shillings may have been the tariff for exemption from around 50 hides. ${ }^{76}$

In short, the Hanbury charter can be interpreted in other ways apart from pointing towards a public sale of fiscal rights of the Mercian monarchy in the age of the Vikings. No less plausible is that, following King Wiglaf's restoration, it may have been intended to proclaim his political power and to build up a network of power between ecclesiastical, royal and aristocratic interests. Given the reference to alms, there may also have been an intention to draw attention to an act of piety connected with other concerns (we shall discuss the issue of sinalienable possessions below). 
Wiglaf's instruction that his donation should act as a marker for future generations was followed by subsequent Mercian kings; however, the opening year of the reign of Berhtwulf began with a high degree of tension between the new king and Bishop Heahberht of Worcester. A charter dated Easter (the 28th of March) 840 recorded that Bishop Heahberht had travelled to the Mercian court with his charters and privileges in order to receive a judgment, resulting in his recovery of five estates which had been unjustly seized from the bishopric through the actions or advice of hostile men. ${ }^{77}$ As part of the peace, Bishop Heahberht promised (predonare) a gift (donatio) to the king and queen made up of a collection of items, including, for the king, four horses (caballae), a ring worth 30 mancuses, a skillfully crafted dish and two silver horns; and for the queen, two horses (equi), two goblets worth two pounds, and a cup. ${ }^{78}$ In total the precious objects were worth just short of 300 shillings (i.e. 295 shillings), roughly in line with Cuthswith's gift to the Hwiccian kings a century and a half before. ${ }^{79}$

The atonement in the Easter Day 840 charter contrasts with the charter that recorded the pious grant of King Berhtwulf at Tamworth on Christmas Day 841 in favour of Abbot Eadmund and the community at Bredon (Worcs.) in the central part of the Hwiccian kingdom. ${ }^{80}$ There are debates over whether this charter is a copy of an authentic ninth-century charter or an early eleventh-century forgery; whether the original grant was in favour of Bredon or of Breedon-on-the-Hill in Leicestershire; and finally whether the Latin used in this charter and another charter (in favour of Breedon-on-the-Hill, and dated to 848) demonstrates the presence of radvanced Latinity in Mercia. It is most likely that the 841 charter is an authentic copy of an earlier ninth-century original intended to favour Bredon, ${ }^{81}$ and for the purposes of the present argument it matters little whether this charter (and the 848 charter in favour of Breedon-on-the-Hill) demonstrates the presence of radvanced Latinity<.

In the Hanbury charter the grant of fiscal liberties accounted for eight of the 30 lines in the printed text, with the remainder of the charter being divided between diplomatic protocol and spiritual matters. But in the Bredon charter only two of the 44 lines dealt with freeing the community from having to support royal agents (frestingmen), with no mention of the common military burdens. The charter was concerned primarily with spiritual matters and the counter-gifts which Abbot Eanmund and his monastic family gave to King Berhtwulf and the Mercian people. There were similarly subtle differences between the organisation of the counter-gifts. In the Hanbury charter these had passed to Wiglaf and two ealdormen, but in the Bredon charter they passed to Berhtwulf and all the Mercian people. Berhtwulf received from Abbot Eanmund a great silver dish that was decorated at a great price and 120 mancuses (300 shillings) in pure gold. The mancus was derived from the Arabic gold dinar, and in 786 Offa had identified the mancus as the preferred form of payment for the annual tribute of Peter's Pence to Rome. ${ }^{82}$ The first extant coin of this value was produced by a moneyer of King Ceonwulf of Mercia (796-821), and the issue was sa direct product of the king for

77 ser in sicut se inimici homines docuerunt suggests the despoliation arose from the advice which the hostile men gave themselves, but sibir may have been meant indicating that they instructed Berhtwulf, as suggested in Whitelock's translation. If sser, perhaps following the death of Wiglaf there was a brief anti-monastic reaction.

78 S192 (B 430; trans. Whitelock, English Historical Documents, no. 86).

79 For a useful discussion of an episcopal gift to Offa, see Curta, Merovingian and Carolingian Gift Giving, 681.

80 S 193 (B 434).

81 Snook, When Aldhelm Met the Vikings, 118-121; King, From Minster to Manor, 84; Tinti, Sustaining Belief, 101.

82 Naismith, Money and Power, 113-114. 
his own purposes ${ }^{83}$ Perhaps the symbolic value of the mancus lay both in its transnational dimension and its close connection to the personal affairs of the king, with counter-gifts in mancuses from prelates emphasizing the royalty of the recipients.

The most striking difference between the Hanbury and Bredon charters lay in the nature of the spiritual counter-gifts and the nature of the witnesses. The Bredon charter was witnessed by a small group of senior clergy, but no ealdormen witnessed it. The four bishops were headed by Cyneferth, bishop of Lichfield, and Bishop Heahberht witnessed third; and Eanmund was the first abbot to witness the charter. The spiritual counter-gift required the community to recite twelve iterations of 100 psalms (psalteria, i.e. the songs of David) and 120 masses for the souls of Berhtwulf, his dear friends and the Mercian people. This can be compared, first, to canon 10 of the Council of Clofesho in 814, which stipulated that on the death of each bishop 30 psalms were to be sung in every church in the diocese, and that each abbot and bishop was to offer at least 120 masses and 600 recitations of the psalter; ${ }^{84}$ and second, to a contemporary West Saxon charter, dated to 854, which recorded the obligation of Glastonbury abbey to perform liturgical services for King Æthelwulf, bishops and ealdormen. ${ }^{85}$ The community at Bredon gave a substantial undertaking and its prescriptive nature separates this charter from the other ninth-century fiscal charters, with Berhtwulf's gift of fiscal privileges described as pietas, echoing the description by Wiglaf of his gift as an act of eleemonsa.

The Bredon charter has been relatively neglected by historians in comparison to the Westbury and Hanbury charters, perhaps because of its theological content, but its evidence is important because it shows that there was at least an intention to uphold monastic traditions in a minster in the mid ninth century, independent of the activities of the bishopric of Worcester and the effects of the Viking invasions. A seventeenth-century copy of a charter of 847 recorded that Bishop Ealhhun of Worcester granted 12 hides belonging to Bredon together with 30 hides at Kelsey minster to the clergy of Worcester, who in turn leased these lands to him for two lifetimes. ${ }^{86}$ This charter demonstrates the strong connections between Bredon and Worcester after the minster was favoured by Berhtwulf, and perhaps suggests that pressure was exerted in the late 840 s on the community to accept the ecclesiastical leadership of the bishop. The hidage attached to Bredon minster between the late eighth and late eleventh centuries is the subject of complex discussion, but in Domesday Book 35 hides were attached to Bredon manor, with 10 hides kept under direct management (demesne) ${ }^{87}$ If one wishes to consider this as a "true sale« at market-value, this would suggest a price of 300 shillings, which was half that received for granting fiscal privileges over a similar number of hides at Hanbury (calculated on the basis of Domesday Book).

In 855, Burgred, king of Mercia (852-74), released the minster at Blockley (Worcs.) in the eastern part of the Hwiccian kingdom from having to feed hawks and falcons in Mercia, from provisioning all huntsmen of the king and ealdormen (except those in the kingdom of the Hwicce), and from provisioning and lodging all men needed for expeditions into Wales and

83 Naismith, Money and Power, 114-115.

84 Cubitt, Anglo-Saxon Church Councils, 194.

85 S 303 (B 472).

86 Dugdale, Monasticon Anglicanum 1, 608.

87 Tinti, Sustaining Belief, 176-183; King, From Minster to Manor; Domesday Book Worcestershire, 2. 22. 
rall mounted men of the English race and foreigners, whether of noble or English birth ${ }^{88}$ In return Burgred received absolution from his sins and 300 shillings in silver, as a counter-gift from Bishop Ealhhun. The grant was witnessed by five bishops and six ealdormen, three of whom had witnessed the Hanbury fiscal charter, including an ealdorman named Mucel. ${ }^{89}$

One way of interpreting the links between the Hanbury, Bredon and Blockley fiscal charters is to assume that each reinforces the evidence of the other in pointing to a crisis in the need for cash and land, leading to the diminishment of the fiscal power base of the Mercian state. The Blockley charter provides no indication of the extent of the estate, but in Domesday Book the manor had 38 hides with 25.5 in demesne. ${ }^{90}$ If model one applies to these fiscal charters, then between 840 and 855 perhaps 300 shillings was the natural price for purchasing exemption for around 36 hides from great and small tributes and dues needed to support fæstingmen, with the price being twice as much for the grant of privileges at Hanbury minster.

But in three of the four fiscal charters we have considered, it is striking that no hidage figures are mentioned. This does not mean that ecclesiastical beneficiaries were unaware of the economic benefits of taxation rights. James Campbell has suggested that the exercise of fiscal privileges was sone of the principal means whereby land was made to produce cash or its equivalent in the centuries before 900. ${ }^{91}$ But for the sale argument to stand, it would be more convincing if the charters dealing with fiscal privileges had provided hidage figures. It is plausible to argue that Burgred in ceding fiscal rights to Blockley minster was seeking to ensure that he should enjoy the same benefits of alliance with the bishopric of Worcester as both his father and King Wiglaf had done. Each of these mid ninth-century kings of Mercia released monastic communities in the Hwiccian kingdom from obligations to support the royal court soon after their accession or restoration, and in each case the king or an ealdorman (with kingly associations) received 300 or 600 shillings as a counter-gift, with these public transactions being witnessed by leading members of the secular and/or ecclesiastical elites. The coincidence both in terms of the cluster of texts and the similarity of the sums proffered by the church may point to a ssocial tariff system < in which it was appropriate for kings to receive gifts of 300 (or 600) shillings, as counter-gifts for gifts of power, from bishops and abbots who ruled over religious foundations in the Hwiccian kingdom. ${ }^{22}$

To summarise, the presence of a cluster of diplomas concerned with the transfer of royal fiscal rights to religious institutions in the Hwiccian kingdom in the early ninth century encourages the view that a common factor lay behind this data. In part this stemmed from the work of the monks of Worcester who designed, compiled and updated the Liber Wigorniensis, which preserves much (but not all) of our evidence. But the cluster can also be interpreted as reflecting an important development during the early ninth century. Following Patrick Wormald's lead, the fiscal charters have been viewed as documents of sale but, as we have seen, there are problems with accepting his view.

88 S 207 (B 488; trans. Whitelock, English Historical Documents, no. 91).

89 For his role in the Hanbury charter, above, nn. 56, 63.

90 Domesday Book Worcestershire, 2. 30.

91 Campbell, Sale of land, 243; see also Naismith, Payments for Land, 284.

92 On social tariff, see Gleba, What is the Price. 
At this stage the second model - that gifts of immunities enhanced the power of royal rulers by expressing >continuity, amity, and co-operation $<$ - beckons. ${ }^{93}$ To do full justice to this model it would be necessary to undertake a prosopographical enquiry, but for the present supporting evidence is poor in both the secondary literature and in PASE. Neither provides much material to suggest that these gifts of immunities linked Mercian kings to local networks of aristocratic donors and their kindred who were in turn connected to the local religious institutions. ${ }^{94}$ Ealdormen Sigered and Mucel and their allies cannot at present be specifically connected with Hanbury and Blockley minsters, nor is there any evidence to suggest that these ealdormen, their companions, and heirs had close connections with the bishopric of Worcester. The absence of any immediate evidence showing that these gifts established networks of power within these monastic communities and with groups of lay grantors, beneficiaries and their heirs is significant, given the richness of the Worcester archive covering the relationship between local networks of family, friends and followers with the bishops of Worcester during the late tenth century and the early eleventh century. ${ }^{95}$ The second model is deceptively straightforward, but in fact this approach may be no more convincing than the first model.

Having tried out the other options, we are left with the third model, that of inalienable possessions. Theoretically kings, ealdormen, frestingmen, messengers and envoys could have continued to carry out their duties after these fiscal privileges had been granted. But, in contrast to the fiscal privilege charter in favour of Breedon-on-the-Hill in Mercia in 848 in a Peterborough cartulary, ${ }^{96}$ there is no evidence to suggest that within the Hwiccian kingdom the Mercian kings continued to expect the hospitality rights associated with these agents from the minsters at Bredon, Blockley, Hanbury and Westbury, as recorded in the Liber Wigorniensis and BL Cotton Ms Augustus II 9. Subsequent efforts to meet ordinary royal household expenditure depended upon the mobilization of new levers of fiscal power as opposed to the recovery of these rights within the Hwiccian kingdom. ${ }^{97}$ Gifts of power ceded to the church in the kingdom of the Hwicce were evidently not the kind of inalienable possessions that are familiar to medievalists who discuss royal crowns, saints' relics, commemorative tapestries and suchlike, and hence the standard version of the third model would not, as it stands, provide a better fit for the data than the first and second models.

But Weiner's suggestion that gift-giving might serve to draw attention to more valuable non-circulated possessions might be relevant for understanding the fiscal charters. The counter-gifts which passed from Hwiccian bishops and abbots to kings of Mercia were perhaps symbolic gestures used to signal ecclesiastical recognition of royalty. Gifts of 300 or 600 shillings appear as the counter-gifts given by prelates from Abbess Cuthswith to Bishop Ealhhun c. 704-855 to kings who ruled over the Hwiccian kingdom, in exchange for grants of land and power. Perhaps there was an expectation within the kingdom of the Hwicce that

93 Rosenwein, Negotiating Space, 84-85; see also above n. 6. For Rosenwein's comments on Anglo-Saxon England, Rosenwein, Negotiating Space, 191-195.

94 Such an enquiry would be best served by beginning with the data in PASE for Mucel 2, Mucel 3, Mucel 4, Mucel 5, Sigered 4, Sigered 5, and Sigered 6, and with the charters drawn up in the 840s in favour of Bredon and/or Breedon.

95 King, St Oswald's tenants; Wareham, St Oswald's Family and Kin.

96 S 197 (B 454).

97 E.g. S 215 (B 540) discussed by Tinti, Sustaining Belief, 11; for a useful comparative discussion, see White, Politics of Exchange, 169-174. 
an appropriate counter-gift to be proffered to rulers for the receipt of gifts of power and land was 300 shillings or 600 shillings. Three of the four gifts of power were made soon after the accession or restoration of a new king, and even Offa's grants to Westbury minster might be interpreted as part of the initiative to ensure the succession of his son Ecgfrith..$^{98}$

In this scenario, the non-circulated goods of the three common military burdens were more important than the dues and services ceded to religious foundations. Army service, fortress- and bridge-work were either not mentioned at all, or were specifically reserved to the Mercian kings. The fact that these obligations were a Mercian innovation emphasises the importance of the exclusion or omission of these fiscal gifts from these charters. ${ }^{99}$ This was a right which the Mercians were unwilling to cede, thereby drawing attention to their role as war-leaders in the struggle against the Vikings and other enemies. Perhaps the use of corresponding sums of money as counter-gifts acted as a way of nodding before royalty. ${ }^{100}$

Our concern has been with fiscal immunities covering the lands attached to monastic communities, but it is worth mentioning one urban charter dating from this period. In 857 King Burgred granted Bishop Ealhhun commercial rights in London, comprising the right of a liberty to conduct trade in Celomundhaga, together with the right to use scales, weights and measures freely ras is customary in the port.$^{101}$ Earlier these rights had been purchased from Ceolmund the prefect in exchange for a counter-gift of 20 shillings, but the bishop gave the king 60 shillings. The increase in the level of the counter-gift may have arisen from the increasing value of these commercial rights in the mid-ninth century, with the property being referred to as a 'profitable little estate ${ }^{102}$ but it is no less likely that this threefold increase in the counter-gift reflected the deference due to the Mercian king in contrast to that owed to a prefect.

If Weiner's variation of the third model on inalienable possessions provides a good fit for explaining the cluster of Hwiccian fiscal charters, there is no reason to suppose that they demonstrated either that the Mercian kings had run out of land and money in the ninth century, or that they needed to build up connections with powerful local aristocrats whose power was linked to religious institutions. Instead, through these gifts of power Mercian kings secured the recognition of their royal authority, and drew attention to the three common military burdens from whose obligations the recipients were conspicuously not relieved. These were inalienable royal possessions, and served to emphasize the military power and authority of ninth-century rulers and their successors. The charters in favour of Hanbury minster and its counterparts were copied and ordered within the Liber Wigorniensis to provide the bishopric of Worcester with a sound history and a firm legal claim to land and power, but the original context of the grants was far removed from those concerns. If historians want to argue that Mercian royal power was in decline in the early ninth century they are free to do so, but it cannot be said that sufficient conclusive evidence for such a view is to be found in gifts of power to religious foundations in south-west Mercia.

98 Kelly, Offa.

99 Brooks, Development of Military Obligations.

100 This view lends further credence to doubts over the Mercian >dynastic reconstruction model on the presence of a rivalry between the so-called Mercian $>\mathrm{B}<,>\mathrm{C}<$ and $>\mathrm{W}<$ dynasties in the ninth century. For a well-judged critique of this view, see Keynes, Mercia and Wessex, 315-320.

101 S 208 (B 492; trans. Whitelock, English Historical Documents, no. 92).

102 On prosopographical research see Ceolmund 5 and Ceolmund 6 in PASE; Whitelock, English Historical Documents, 529. 


\section{Part II: Khmer kings and their religious foundations ${ }^{103}$}

The Khmer epigraphical record consists of about 1300 stone-cut inscriptions in Sanskrit (like Latin in Europe, this was the long dominant hierolect in large swathes of Asia), or in Khmer (the dominant local vernacular), or in a combination of both languages, and spans from the fifth to the thirteenth century. No texts in any language transmitted through manuscripts to the present day survive from Cambodia for the whole of this period. This means that, other than sporadic Chinese accounts, ${ }^{104}$ those roughly 1300 inscriptions, and the ingenuity of archaeologists and art-historians who study the extraordinary buildings with which those inscriptions are associated, are all that we can call upon to tell us about Cambodian history for the entire period covered by this special issue.

I have referred to >Cambodian< history, but this inscriptional corpus of the Khmers is spread well beyond the boundaries of modern Cambodia, for the so-called Khmer empirer at its tenth- to twelfth-century height extended westwards into areas that are now part of Thailand, reaching from the Mekong river delta in the south, in what is now Vietnam, up into what is now Laos in the north, and including therefore Vat Phu, the site of the discovery of the inscription under discussion here. At the heart of this sempire<, covering an area many times larger than that discussed above of south-western Mercia, is Cambodia's most famous site, the great concentration of ancient buildings now often known as Angkor, which is just north of Cambodia's seasonally swelling and shrinking lake, the Thonle Sap. Broadly speaking, the inscriptions and archaeological data of the fifth to the eighth centuries tend to be concentrated in the area around the Mekong river delta in the south, suggesting the economic centrality of foreign trade in that period, whereas from the ninth century onwards they tend to be concentrated inland, north of the great lake, ${ }^{105}$ suggesting a shift to an economy in which agriculture had a larger importance. Vat Phu, up-river in Laos, however, has been an important sacred site from the early period onwards. ${ }^{106}$

The Sanskrit portions of these inscriptions are metrical and typically lavish samples of erudite courtly poetry praising the Hindu pantheon and Khmer kings, before recording the installation of an image of a Hindu or Buddhist deity or, most commonly, of a linga - a phallic (or, for some, aniconic or abstract) physical substrate for the worship of the god Siva. These Sanskrit texts are very often supplemented by portions of prose in Khmer which furnish down-to-earth details about the foundations. (Such a division of labour between hierolect and vernacular is similar to what we observed in the Mercian charters discussed above. ${ }^{107}$ ) Old Khmer is not a particularly well-understood language and many of the inscrip-

103 Long confessions of incompetence can be tedious, but I must briefly state that I am not an economic historian and that this subject is outside my usual area, namely the textual-critical study of Sanskrit poetry and the history of the theology and ritual of the Śaiva religion. I have strayed here because of two factors: the influence of my brother-in-law and the serendipitous happenstance that an important unpublished tenth-century document about Cambodian taxes came into my hands, through my colleague and collaborator Claude Jacques, in 2013.

104 For which see Pelliot, Fou-nan (1903) and Mémoires sur les coutumes (1951).

105 This shift, along with the social and political changes that accompanied it, is a large theme in one of only two books known to me that attempt an economic history of ancient Cambodia, namely Michael Vickery's stimulating Society, Economics, and Politics in Pre-Angkor Cambodia, the 7th-8th Centuries. As the title indicates, it does not cover the period with which we deal here. The other book is Sahai's Institutions politiques et l'organisation administrative du Cambodge ancien.

106 The first century of scholarship on the extraordinary site of Vat Phu has been usefully gathered together in Lorillard's Autour de Vat Phu.

107 A lively book-length exploration of the rôles of Sanskrit is Pollock's Language of the Gods in the World of Men. 
tions are damaged, but a certain repetitiveness in the material often helps one to interpret even tiny fragments. For many hundreds of passages of Khmer epigraphy are devoted to listing the gifts of wealth and property to named gods: cattle, lands, objects fashioned out of precious metals and slaves. ${ }^{108}$

The epigraphical record is dense for the seventh century, has some empty patches in the eighth and ninth centuries, and is then very dense once again from the end of the ninth through the beginning of the thirteenth century, after which inscriptions of this type are no longer found and the Hindu-Buddhist civilisation that was characteristic of the Khmers disappeared entirely. Why? One way towards an answer might be some form of the general hypothesis that the granting of excessive religious immunities eventually weakened the state to the point at which it became vulnerable to incursions from the outside and collapsed. Precisely this interpretation has indeed been tentatively mooted by Victor Lieberman:

One approach [to the problem of Angkor's decline] - which parallels Aung-Thwin's Pagan hypothesis but lacks his careful documentation - argues that over time politically indebted kings alienated excessive tax-exempt acreages to aristocratic supporters, who were able to pursue power through religious munificence in competition with the king himself. This in turn obliged the crown to attempt more lavish projects of its own, which ultimately exhausted the realm. ${ }^{109}$

Yet it seems to me that there are hundreds of things that one would have to understand profoundly in order to be able to judge the merits of such a hypothesis. One would wish to know, for instance, about conceptions of property, land-use, slavery, and kingship. Did kingship here, for example, involve real centralized control of all resources of the territory of the kingdom, or was it a more theatrical show of hierarchical superiority shored up by religious notions and ritual? To illustrate this sort of conceptual difficulty without delving deep into the abundant theoretical lucubrations of historians of the ancient world about kingship, let us briefly turn to the fifth-century literary epic of Kālidāsa about a legendary dynasty of rulers descended from the sun, namely the Raghuvamía.

Of all the poets of the Sanskritic thought-world, Kālidāsa is the most quoted and echoed in pre-modern inscriptions from Afghanistan in the West across to South Vietnam and the Indonesian archipelago in the East. And of all Kālidāsa's works, it appears to have been his Raghuvamiśa that was most savoured, and within that epic it is probably the fourth chapter

that court-poets most imitated. The fourth chapter recounts an autumnal military campaign by the king Raghu to gain victory over all the kings around him in every direction right up to the ocean's shore. At the end of this Conquest of the Directions (digvijaya), it is clear, however, that no value is placed upon retaining centralised political control of the resources of the territories that have been, so to speak, sconqueredr. Instead, all the wealth is returned as part of a grand ritual, and the rival kings, their status duly diminished, are allowed to return to their capital cities to resume their royal rôles.

108 'Slavery is an emotive term that can be applied to peoples of widely varying status: for a lively discussion of sslaves in ancient Cambodia, see Vickery, Society, Economics, and Politics in Pre-Angkor Cambodia, $225 \mathrm{ff}$.

109 Lieberman, Strange Parallels Vol. 1, 238. 
Thus did the Conqueror vanquish all directions and then turn back, scattering the dust thrown up by his chariot upon the diadems, now bereft of their parasols, of rival kings. (88)

He [then] performed an sAll-Conquering sacrifice, at whose conclusion the ritual donation is all one's wealth: indeed, like clouds, the great only take in order to give. (89) At the end of that sacrifice of many days, Raghu, with his ministers beside him, allowed the kings to depart, their grief in defeat assuaged by weighty gifts, to their various capitals, where they were longed for by long-separated wives. $(90)^{110}$

The very numerous references in Indian inscriptions to multiple conquests, sometimes even by neighbouring kings of each other, have often caused puzzlement to epigraphers and have led to a tendency to underestimate the historical value of such records generally, lending support to the dubious but endlessly recycled claim that IIndia had no sense of history<. But in the light of Kālidāsa's idealising vision, it is clear that we should expect some rconquests` to have been more like shit-and-run raids than campaigns resulting in the expansion of the control of resources over a broader territory. I have picked out the concept of royal sconquests for brief comment, but this single example suggests that there may be several apparently obvious notions about kingship and property that in fact require re-examination before we blithely subscribe to the theory that reckless munificence to religious foundations bankrupted the Khmer empire and led to its demise.

As it happens, a significant piece of evidence that perhaps bears upon these questions came into my hands in 2013. ${ }^{111}$ It is a document that seems to contain the only known list of what was to be paid by a Khmer administrative region in annual taxes in Angkorian times.

110 iti jitvā diśo jị̣nur nyavartata rathoddhatam/ rajo viśramayan rājñām chattraśünyeșu maulișu 88 sa viśvajitam äjahre kratum sarvasvadakșinam/ ädānam hi visargāya satāṃ värimucām iva 89 sattrānte sacivasakhah puraskriyābhir gurvībhih śamitaparājayavyalīkān/ kākutsthaś ciravirahotsukāvarodhān rājanyān svapuranivrttaye 'numene 90.

From the edition of Goodall and Isaacson, Raghupañikä of Vallabhadeva. For a discussion of such poetry, see the different approach taken by Sinha in this special issue.

111 The accidental discovery of the four-sided stela (now inventoried by the EFEO as K. 1320) was reported in the Vientiane Times in January 2013 (www.vientianetimes.org.la/FreeContent_Ancient.htm, consulted on 15th January 2013; the page has since disappeared!), and the exceptional circumstances of its situation were quickly written up by Christine Hawixbrock (La stèle inscrite K. 1320). Beautifully legible photographs, taken by David Bazin, were passed to Claude Jacques, and we together studied the entire inscription over the course of many weekly sessions of the "séminaire CIK" (Seminar [related to the project] Corpus of Khmer Inscriptions) at the École pratiques des hautes études in Paris. This enabled us to polish an edition and translation that has appeared in the latest issue of Aséanie (Goodall and Jacques, Stèle inscrite d’İśānavarman II à Vat Phu: K. 1320). 


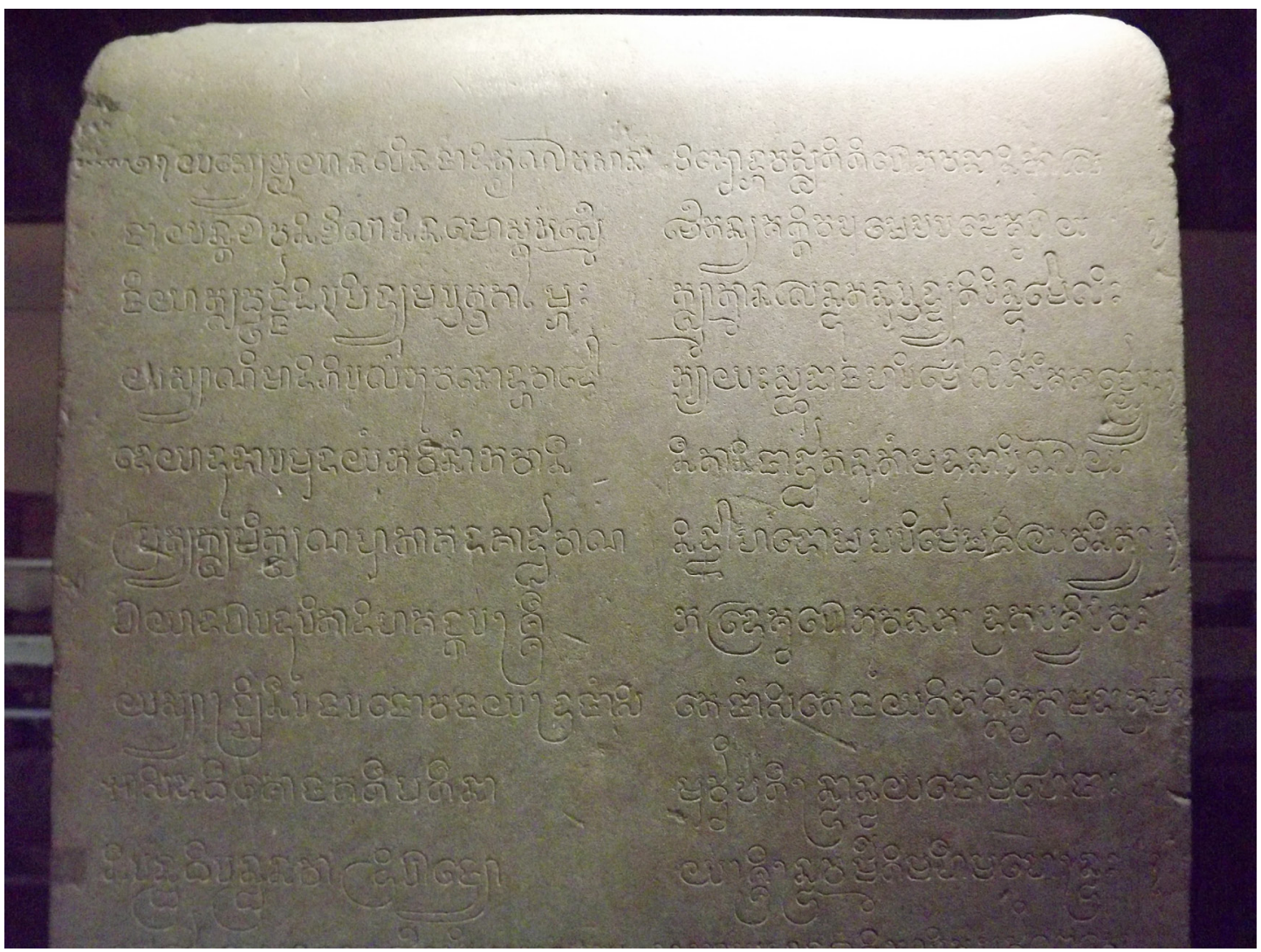

Fig. 4: The inscribed stela, K. 1320

The text, composed in Sanskrit and carved in Khmer letters typical of the tenth century in a fine calligraphic hand onto a four-sided sandstone stela, had clearly been buried for centuries, perhaps from shortly after the time of its creation, since that would account for its near perfect state of preservation. With the Mekong to one's back, as one sets off to climb up to the shrine of Siva perched on the side of a mountain with a peak that was for many centuries considered to have the shape of a linga, two eleventh- or twelfth-century building-ranges flank the approach at the base of the slope. The four-faced stela, dated to the beginning of the tenth century, was found upright but beneath the ground, with its summit at the level of the raised paving in the entrance to the building range to the right of the approach (the northern side). The two building-ranges have been referred to as 'palaces`, but it now seems not impossible, in the light of the contents of the inscription that we are about to examine, that they should have been built partly to serve as warehouses for tribute that was offered to the temple. 


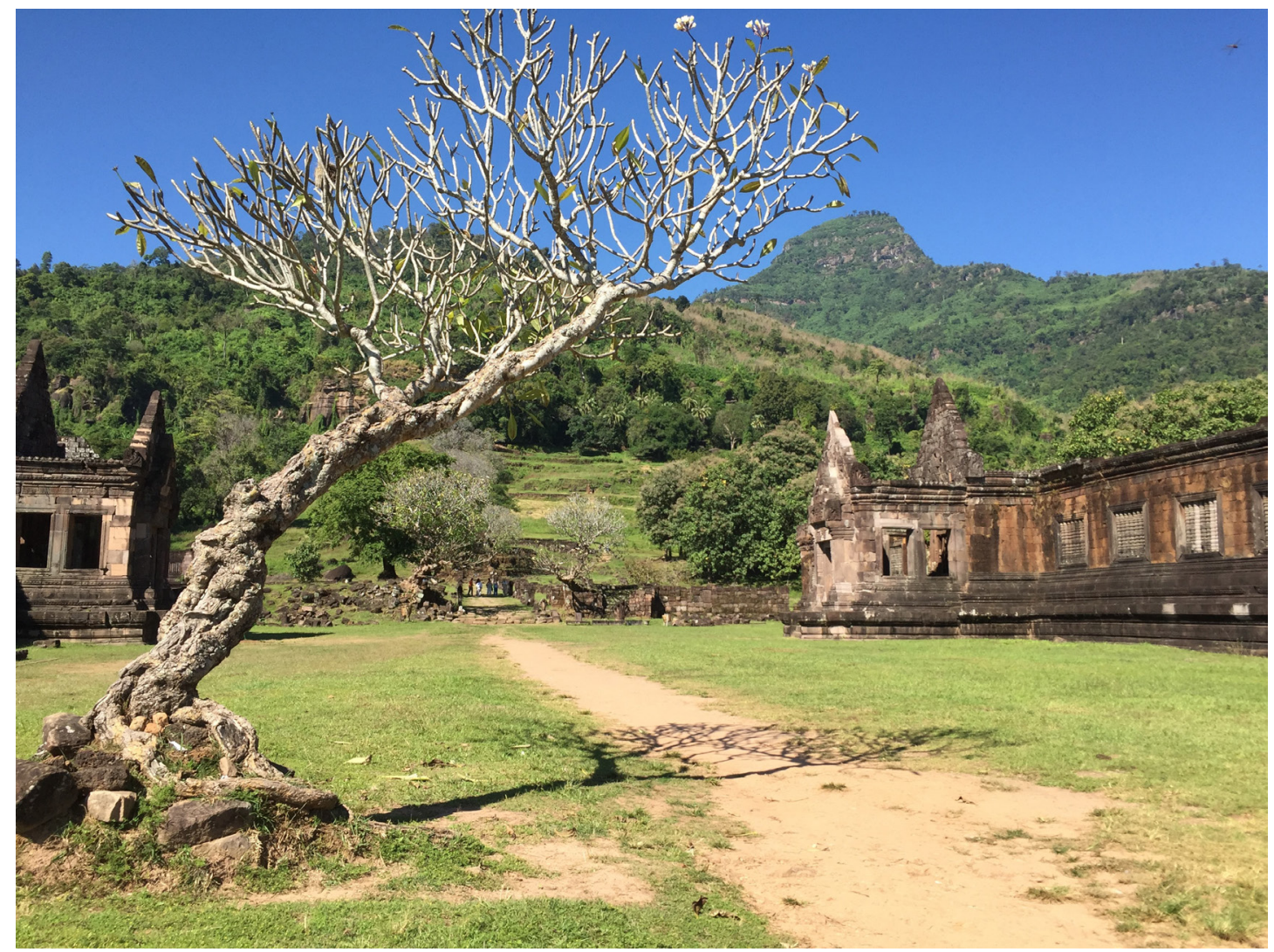

Fig. 5: The approach to the temple of Siva at Vat Phu. The four-faced stela K. 1320 was found at the entrance of the building range to the right. (photo: Dominic Goodall)

The epigraph consists of 96 Sanskrit stanzas and begins with invocations to Siva and other gods (verses 1-4), followed by short eulogies of three Khmer sovereigns, recording in each case their years of accession, namely Indravarman I (verses 5-17, accession in 877), Yaśovarman I (verses 18-25, accession in 889) and Harșavarman I (verses 26-33, accession in 910). After this, there is a longer eulogy, in florid and extremely erudite courtly Sanskrit, of the then reigning monarch, Ísaanavarman II (verses 34-59, accession in 925). Since we know that this monarch died in $928 \mathrm{AD}$, we can thus pin down the date for the stela to within three years. Thereafter, almost the whole of the fourth and final side of this stela (verses 61-90) is devoted to a list of the annual taxes owed to the king by the town or administrative district then known as Lingapura (sthe city of the lingar), with explanations to the effect that these taxes are henceforth to be paid instead to the Siva of Vat Phu, in other words to the temple. A grandiloquent exhortation to future kings to respect the terms of the edict concludes the text (verses 91-96). The one verse that I have omitted from the above summary is that in which there is the clearest statement about the transfer of the annual taxes to Siva. The verse in question occurs just before the list (bottom of Face C, lines 39-40, verse 60): 
In his [first] regnal year, this king of the Kambujas received tribute from vanquished kings; but, being himself vanquished by devotion, he bestowed upon the [God] Śiva in this place the taxes which are to be levied annually from Lingapura: ${ }^{12}$...

These taxes are not expressed in terms of money, for the Khmers at that period, even though they had been in constant contact for centuries with India, appear not to have been using coinage as money. ${ }^{113}$ The only epigraph that might be supposed to contain a reference to coinage in the entire inscriptional corpus is a ninth-century record of which only a few disjointed fragments can be read. ${ }^{114}$ Instead, the taxes were to be paid in a variety of forms, which I have grouped into categories in the tables below.

\begin{tabular}{|l|l|l|}
\hline \multicolumn{2}{|l|}{ Precious Metals } & \\
\hline Gold & & \\
\hline nuggets & 600 pala & $3.54 \mathrm{~kg} / 22.5 \mathrm{~kg}$ \\
\hline red gold & 15.5 pala & $91.45 \mathrm{~g} / 581.25 \mathrm{~g}$ \\
\hline Silver & & \\
\hline goblets weighing & 8 kațtikā & $960 \mathrm{~g} / 6 \mathrm{~kg}$ \\
\hline
\end{tabular}

The silver and the so-called red ' gold ${ }^{115}$ is to be given in the form of goblets and ornamental lotuses respectively, to be offered on annual visits by three classes of administrative official. The other gold, since it is in nuggets, must presumably be derived from local panning activities in the tributaries of the Mekong.

A tricky problem with this data is immediately apparent from the table: while we can know (from Sanskrit texts transmitted in India) how units of measure are related to one another proportionally, they clearly had no absolute value for every period and region. For Angkorian Cambodia, there is not only no consensus about what their absolute values were, but the estimates of those values are very widely discrepant. I have provided here the metric values calculated from the two most recent estimates known to me, those of Claude Jacques and Dominique Soutif, ${ }^{116}$ whose much lower estimate is based on the discovery of a bronze

112 K. 1320, stanza 60: sa kamvujendro nijarājyaśäke jïtān nṛpād dāyam upājahāra / jitas tu bhaktyātra hare 'nuvarșalabhyam karam lingapurād vyatärït.

113 The only hitherto discovered ancient Khmer coin is a seventh-century gold one noticed by the archeologist Guillaume Épinal at an antique dealer's in Phnom Penh, and reportedly picked up from the ground in Angkor Borei. It has been described and illuminatingly contextualized by Joe Cribb (Cribb, First Coin of Ancient Khmer Kingdom), who demonstrates, by comparison with contemporary Eastern Indian coinage, that it is indeed a coin (rather than just a medallion) but at the same time clarifies that it is unlikely to have been part of a widely used coinage.

114 The inscription in question is K. 492, published in $I C$ vol. II, in which the otherwise unattested word sarängi occurs twice, each time in a sentence rendered incomplete by damage. Cœdès records there that he tentatively follows Louis Finot's suggestion that one should understand särangi (which would in fact be unmetrical in one of the two instances), which he took to be the name of a coin. For the EFEO's inventory numbers of Khmer inscriptions from K. 1 to K. 1005, which are used here and throughout this article, see the list published by Cœdès (IC vol. 8).

115 We do not know what sort of gold is meant by >red gold. It is more fully characterised, several times, as having redness and six qualities (rāgașaḍuṇa).

116 See Goodall and Jacques, Stèle inscrite d'İśānavarman II, 449-450 and Soutif, Organisation religieuse et profane du temple khmer, 132-153. 
vessel that is labelled with what might be intended to be a statement of its weight. Even when they are comprehensibly quantified, gauging the values of many of the other tradable items in the list is no easier.

\begin{tabular}{|l|l|l|l|}
\hline \multicolumn{3}{|l|}{ Animals and Animal Products } & \\
\hline Quadrupeds & & turtles & \\
\hline boars & 160 & elephants & 200 \\
\hline monitor lizards & 200 & & 10 \\
\hline Birds & & & \\
\hline parakeets & 100 & & \\
\hline Peacock parts & & wing-feathers & 400 \\
\hline tail-feathers & 12000 & & \\
\hline $\begin{array}{l}\text { neck-pouches } \\
\text { (?) }\end{array}$ & 20 & & \\
\hline Other animal parts & & & 12 \\
\hline elephant tusks & 20 & rhinoceros horns & 12 \\
\hline boar-skins & 20 & & \\
\hline
\end{tabular}

We can have only vague ideas about what these animals and animal parts were worth to the citizens of Lingapura or to the King at the time.

The same may be said of the weapons and utensils listed.

\begin{tabular}{|l|l|l|l|}
\hline Weapons and Utensils & & & \\
\hline Weapons & & crossbow arrows & 100 \\
\hline crossbows & 5 & arrows & 2000 \\
\hline bows & 100 & Khmer axes (?) & 40 \\
\hline cuirasses & 100 & & \\
\hline Utensils & & brooms & 300 \\
\hline parasols & 200 & bell-metal goblets & 30 \\
\hline gourds & 218 & & \\
\hline rattan poles & 800 & & \\
\hline Clothing & & & \\
\hline $\begin{array}{l}\text { Pairs of upper + lower } \\
\text { body-cloths }\end{array}$ & 2230 & & \\
\hline
\end{tabular}

The gift of these weapons to a temple might seem odd, and one might be tempted to infer that Vat Phu, in spite of being a site of spiritual centrality for Khmer rulers, was nonetheless sufficiently far from the centre of power to require its own protection force. But we must be cautious about leaping to such a conclusion, since the weapons may only feature here because they were tradable items ${ }^{117}$ or because this is a wholly unmodified list of what had previously been due in tax to the king.

117 Hundreds of axes feature, for example, among the miscellaneous items used to purchase two paddy-fields in an almost exactly contemporary inscription, K. 159 (see IC 2, 111). 
The following fragrant substances are more clearly tradable luxuries:

\begin{tabular}{|c|c|c|}
\hline Fragrant substances & & \\
\hline \multicolumn{3}{|l|}{ Oleo-resins } \\
\hline takka (pine-resin) & 1300 kaț̣ī & $156 \mathrm{~kg} / 975 \mathrm{~kg}$ \\
\hline \multicolumn{3}{|c|}{ taruṣka (`Turkish`Styrax) in 4 forms: } \\
\hline >Camphor & 2 kaț̣ī & $240 \mathrm{~g} / 1.5 \mathrm{~kg}$ \\
\hline liquid form & 3 prastha & 3.751. \\
\hline fragments & 5 prastha & 6.251. \\
\hline Powder & 2000 vaniśa & $?$ \\
\hline \multicolumn{3}{|c|}{ Other fragrant substances } \\
\hline nābheya (musk) & 200 kațțī & $24 \mathrm{~kg} / 150 \mathrm{~kg}$ \\
\hline Neem-tree-hearts (?) & 2 khārī & 1601. \\
\hline pracivala (vetiver) & 10 khārī & $8 \mathrm{hl}$. \\
\hline
\end{tabular}

These were presumably harvested, if not actually farmed, from the forest area around Lingapura. Arguably, they occupy a relatively large place in this list compared with farmed comestible produce.

\begin{tabular}{|c|c|c|}
\hline Foods & & \\
\hline \multicolumn{3}{|l|}{ Grains } \\
\hline Threshed rice & 100 khārī & 80 hl. (6 tonnes?) \\
\hline Paddy & 2000 khārī & 1600 hl. (120 tonnes?) \\
\hline Sesamum & 21 khārī & 16.80 hl. (1260 kg?) \\
\hline Millet & 21 khārī & $16.80 \mathrm{hl}$ \\
\hline māșaka beans & 16 khārī & $12.60 \mathrm{hl}$ \\
\hline Mung beans & 105 khārī & 84 hl. (6300 kg?) \\
\hline \multicolumn{3}{|l|}{ Spices } \\
\hline Ginger & 20 katțī & $2.4 \mathrm{~kg} / 15 \mathrm{~kg}$ \\
\hline Turmeric & 5 khārī & $240 \mathrm{hl}$. \\
\hline Long Pepper & 5 kațtīi & $6 \mathrm{~kg} / 37.5 \mathrm{~kg}$ \\
\hline Medicinal Roots & Unlimited supply! & \\
\hline
\end{tabular}


Such farmed produce is rather more prominent in the only comparable lists we have, which are not tenth-century taxation edicts, ${ }^{118}$ but twelfth-century lists of produce that is required annually for the regular running of a couple of very large temples (known today as Ta Prohm and Preah Khan) in the Angkor area. ${ }^{119}$ This is perhaps natural given that Vat Phu was probably then, as today, surrounded largely by forested land.

Finally, we may note in passing that the slaves of the temple are excluded from royal corvées and the like.

The slaves of Śrī Bhadreśvara, ${ }^{120}$ who push back darkness from this world, as well as those of its ashrams, should not be engaged to perform the works of the king, nor commanded to pay tributes by district governors or by others. ${ }^{121}$

This disposition is similar to what we find for two other late-ninth-century religious shospitals (ashrams) in the same area, in today's Laos. ${ }^{122}$

Other than our inability to assess the commercial value of, for instance, all the animals and animal parts, there are several other considerations that suggest that this list of tax demands is very different from a cash stipulation. If one imagines such taxes being offered annually and in kind to the king, the transportation must have been complicated and costly to arrange. It is true that a broad swathe of the Mekong sweeps majestically past the bottom of the Linga-shaped mountain at Vat Phu, but a considerable stretch of the river further south is not navigable. Thus even if boats were involved, other means of transport must have been needed for some parts of the journey. The use of wheeled vehicles seems unlikely in such a mountainous area at this time, ${ }^{123}$ and our inscription suggests that the default option was to use elephants as draught animals:

118 There is perhaps one distant parallel, namely a very short eleventh-century list of annual taxes due from a single village that are transferred to a temple: 4 measures (thlvañ) of rice; 1 measure (mäs) of oil; 1 white parasol and 1 banner (K. 211 of $1037 \mathrm{AD}$, for which see IC 3, pp. 26-28). Sahai (Institutions politiques, 119) mentions this inscription as evidence that some taxes were paid annually and collectively.

119 These have been published, in each case with a French translation, by George Cœdès in articles entitled "La stèle du Ta-Prohm « (1908) and "La stèle du Práḥ Khăn d’An̉kor« (1941).

120 Bhadreśvara is the consecration-name given to the linga in the temple in Vat Phu. Put in other words, it is a name used for Śiva when he resides in the principal substrate of worship in the temple there.

121 K. 1320, stanza 90: ye kinkarā lokatamonudaś śri-bhadreśvarasyāpi tadāśramānām / te rājakāryyeșu na yojanìyā na dāpyadāyā vișayādhipādyaih.

122 Cf. the foundation stelae for ashrams at Huei Thamo (K. 362), also in Laos, and Vat Phu (K. 1005, for which see the discussion of Estève and Soutif, Yaśodharāśrama, marqueurs d'empire, 342-343), both dated to 889 AD:

deśädhyakṣädyanāyattās te syur āśramakinikarāḥ

paratantrāh kulapatau tāpase ceti śäsanam //

"Que les serviteurs de l'áśrama ne soient pas mis en réquisition par le gouverneur de la province et les autres fonctionnaires, et qu'ils soient (uniquement) aux ordres du chef de la communauté et des religieux. Tel est (notre) commandement." (Bergaigne, Notices et extraits des manuscrits de la Bibliothèque nationale, 390). Cf. also the stela of Lolei (Siem Reap) K. 363 (889 AD), st. LXV:

śrindravarmmeśvarādināṃ devānām sarvvakinikarāḥ

viśvambharādhiräjena na niyojyās svakarmmaṇi //

"[Whoever should in the future be] the supreme king of the earth should not employ for his own works any of the slaves of [the Siva called] Indravarmeśvara or of the other gods."

123 Barth, Stèle de Vat Phou, 240, interprets the word yāna in a seventh-century inscription at Vat Phu (K. 367, stanza 5) as a "char «, but Barth himself never saw the terrain. It seems more likely that the expression referred to palanquins or animals which one could mount. 
If, in order to make possible the supplying of these gifts, the head of the [administrative region known as the] visaya has procured noble elephants using his own wealth, those [elephants] are not to be added to the god's possessions. ${ }^{124}$

The difficulties involved in transporting them imply that offerings in kind presumably varied considerably in value depending on where they were geographically when they were offered. Almost all the items in our list seem clearly to have been harvested or gathered locally, from a mountainous forest abounding in animals and trees yielding perfumed resins. Would their value as precious trading-items not have been lower when they were stored in the warehouses of the temple on the side of the mountain from which they were gathered than when they had been delivered to the king in his capital, hundreds of miles distant by boat and elephant-ride? The gold nuggets panned from tributaries of the Mekong were perhaps the only locally gathered offerings whose local value may not have differed significantly from their value at the empire's centre. But it is probable nonetheless that even the items in precious metals were not of fixed monetary value. We have mentioned one consideration that suggests this: some of the gold in the list, as well as all of the silver, was not simply to be totted up with the other taxes, but was instead to be shaped into flowers and goblets and offered by particular visiting dignitaries when they paid visits of obeisance. Here, for example, in the middle of the list, is a verse that describes what should happen when a certain official, who might have been a sort of inspector, visits:

When an inspector from this country prostrates himself, a lotus in gold [of the type called] rägasadguna of the weight of one pala [and] a cup of pure silver weighing one kațtikā [are to be offered to Siva]. ${ }^{125}$

Some extra quantities of some of the oleo-resins were also to be presented on such visits. Were these official visits to the Siva of Vat Phu also part of the legacy transferred from the king? Did these officials, in other words, make such formal gift-giving visits to the king (perhaps on the occasions when they submitted the taxes, or instalments of them) before this edict was issued? Unfortunately the inscription gives us no clue. In any case, we can conclude from the foregoing paragraphs, firstly, that it seems unlikely that the items in this list would at any time have had a single market value throughout the Khmer empire; and secondly, since the offerings were not all simply handed over together or at some indifferent moment in the year, but had in some cases to be offered ceremonially by particular officials, it is probable that their value as offerings was not simply determined by some notional exchange value, but depended in part on the formal context in which they were given.

124 K. 1320, stanza 94: upāyanaṃ śakyam idaṃ vidhātum matangajendrā vișayādhipena / yadi svavittais samupārjjitās te devasvasamparkkam anāptavantah.

125 K. 1320, stanza 87: taddeśaje janādhyakșe praṇate rägașadgunam / hemapadmapalam śubhrarajatāmatrakatțikā. 
Clearly the temple of Śiva at Vat Phu was of singular importance in the religious geography of the Khmers. Numerous inscriptions from other temples across the Khmer-speaking world refer to gifts made to the Siva of Vat $\mathrm{Phu}^{126}$ and many temples adopted his distinctive theonym, Bhadreśvara. ${ }^{127}$ Furthermore, inscriptions at several sites in distant parts of the Khmer empire record the practice of twinning the deity of a newly established temple with the Siva of Vat Phu and declaring that the new temple's revenue will be shared with Siva in Vat Phu. We may quote as an example a passage from an inscription at Vat Práh Ěinkosěi (Siem Reap), K. 263 (post 968), Face C, 25-27: ${ }^{128}$

The broad-famed Lord Bhaț̣a Divākara - son-in-law of King Rājendravarman, the crest-jewel of all the princes of the earth, whose Victory straddles the worlds, and the brother-in-law of King Jayavarman [the fifth] - established three gods in Madhuvana and dedicated them to [the Śiva of Vat Phu, who is called] Bhadreśvara. (25)

[He] endowed [them] with golden palanquins and such like riches, [made them] gleam with diverse jewelled ornaments, and [made them] abound with land, silver, copper, gold, cattle, male and female slaves, buffalo, horses and elephants. (26)

Having decreed that their revenue was to be shared with Bhadreśvara, His Excellency Himself made an annual gift of six khärikā of unhusked rice as food for visitors. (27)

The earlier-mentioned gifts of land, slaves, wealth and precious objects that figure in distant inscriptions seemed readily understandable as indications of the importance of Vat Phu as a focus of devotion and therefore prestige. But what are we to make of these declarations of divinities sharing what is offered to them with the Siva of Lingapura? No doubt for these too the high prestige of making offerings to the Siva of Vat Phu must have been a motivating factor, but is there more to be seen? Here is Ian Lowman's illuminating explanation of this phenomenon. ${ }^{129}$

126 Aside from K. 1320 (c. 926 AD), we may refer for instance to the following epigraphs: K. 728 (provenance unknown, eighth-century); K. 528 (Mebon, Siem Reap, 952), st. CCIII (pace Finot 1928); K. 806 (Pre Rup, Siem Reap, 961), st. CCLXXI; K. 720 (Vat Phu, 955-1006 AD); K. 485 (Phīmānàkàs, post 1181), st. LXXXVII; K. 963 (Vat Phu, thirteenth-century).

127 See, e.g., Estève and Soutif, Yaśodharāśrama, marqueurs d'empire, 337.

128 IC, vol. 4, 125-126:

XXV.jāmātā bhuvaneśvarasya sakalakșoninindracūḍāmaner

llokākrāntajayaśriyah prthuyaśā räjendravarmmäbhidheh

devo bhațtadivākaro madhuvane samsthäpya devatrayam

syālaś śrijayavarmmadevanrpater bhadreśvare kalpayat //

XXVI. suvarṇnayānädidhanair upetam vicitraratnäbharaṇapradīptam

prabhūtabhürājatatāmrahemagodāsadāsīmahișāśvanāgam //

XXVII. bhadreśvarenaiva vimiśrabhogañ krtvā(d)ideśa s(v)ayam eva devah

șatkhärikä bhojanatan(du)lānān tadägatebhya(h) prativatsaran ta(t)

Some other examples of this practice may be cited: Prasat Kok Cak K. 958 (947), st. XIX; Banteay Srei K. 842 (968), st. XXXVII; Provenance unknown K. *1171 (1024), st. II. This last inscription is still unpublished. Its text is known to me through the growing archive of electronic texts of the Cambodian corpus being compiled under Dominique Soutif (EFEO) for the project »Corpus des inscriptions khmères«, in which I collaborate.

129 From Ian Lowman's unpublished presentation entitled »Understanding Vat Phu: An Early Khmer Pilgrimage Site«, delivered at the workshop Trans-border Archaeologies: Vat Phu and Angkor, December 15, 2015. 
Lingapura's administrative independence extended to its properties throughout the kingdom, which were likewise exempt from local and royal levies. In consequence, Khmer elites had a special incentive to join their possessions [...] - their temple foundations, personnel, lands, and production - with those of Lingapura. Elites from every corner of the kingdom scrambled to do this throughout the tenth century. Their small provincial temples were required to donate a certain portion of their production and personnel to Vat Phu, and in exchange they were promised independence from powerholders at the level of the visaya or administrative district. As more and more temples were sjoined to Lingapura, we see the rise of an extensive network of subsidiary shrines in dependent relationship to Lingapura, the parent shrine at the top of [the] sacred hierarchy.

This prompts me to return to Victor Lieberman's words, cited above: ${ }^{130}$

One approach [to the problem of Angkor's decline] - which parallels Aung-Thwin's Pagan hypothesis but lacks his careful documentation - argues that over time politically indebted kings alienated excessive tax-exempt acreages to aristocratic supporters, who were able to pursue power through religious munificence in competition with the king himself. This in turn obliged the crown to attempt more lavish projects of its own, which ultimately exhausted the realm.

When I quoted this before, however, I did not quote the concluding sentence of the paragraph:

But in the absence of external coordination, why should these internal processes have climaxed at roughly the same time in both Upper Burma and Angkor?

Lieberman goes on, quoting the recent work of archaeologists and palaeo-ecologists, to stress the likelihood that various man-made environmental changes (soil-erosion, soilsterilisation, clogging of transport canals, land-shortage, sedimentation and animal waste that modified the ecology of the lake), as well as some environmental change produced by a climate shift that simultaneously affected both regions, might well be equally important factors. As Lieberman continues,

Pagan-Angkor synchronization therefore makes sense if we consider that: a) aided in some measure by improved climate, both civilizations entered a period of intense development in the tenth and eleventh centuries; b) reclamation in both areas continued through the thirteenth century; c) in both areas growing desiccation after c. 1280 aggravated resource constraints that three hundred years of rapid development had engendered. According to David Godley, "a major and striking change to the climatological regimes of the region ", namely a "general desiccation of Indochina «, began c. 1280 and continued to the late fifteenth or sixteenth century. This is not to claim that reserves of good cultivable land became exhausted at precisely the same time in both areas, merely that both experienced some combination of ecological and climatic stress. ${ }^{131}$ 
To conclude, the notion that a pressure, for the sake of status, to make prestigious benefactions to religious institutions eventually bankrupted the state and prepared for its collapse in the face of external incursions is extremely seductive (for we are all susceptible to the appeal of a clear narrative), and on the face of it might be thought to be strengthened by the discovery of the tenth-century stela on the taxation of Lingapura. But there are no doubt many other environmental factors that also played their rôles. Furthermore, when we contemplate the raw evidence, we are uncomfortably aware that there are simply too many gaps in our knowledge about what the documents mean and about all the historical and economic contexts, for which they give us such patchy information. Face-to-face with the stela, we realise that we have no notion of the extent of the taxed area and no other comparable tax document; no notion of the values of the units of measure employed; no notion of the relative value of most of the traded items; few notions of who was actually responsible for collecting and inspecting the taxes, either before or after their transfer from the crown to the god; ${ }^{132}$ no certain information about who actually received and administered the wealth on behalf of the god; ${ }^{133}$ and no notion of whether the taxation scheme was adhered to, for the king appears to have ruled for no longer than three years and the stela may have been buried very soon after being carved.

Furthermore, other than that Vat Phu is mentioned in many grants from widely distant areas as receiving further endowments in the tenth century, we know rather little about what happened at Vat Phu in the century preceding or the century following the inscription. ${ }^{134}$

132 Such details as we can glean from scattered inscriptions about such officials have been grouped into a chapter entitled >Le régime fiscale in Sahai’s Institutions politiques, $113 \mathrm{ff}$.

133 A certain Subhadra, who took the initiation-name Mürdhaśiva, is glorified in a twelfth-century Sanskrit poem inscribed on a stela at a temple a few kilometres away from Vat Phu at Ban That (K. 364), and that Subhadra is said to be the descendant of a sage (whose name is lost to damage) who installed the linga at Vat Phu. There seems, in other words, to have been a family who in the twelfth century claimed authority, by heredity, over the performance of worship in the Vat Phu temple, and therefore presumably also control over its resources. But did they really already enjoy such a rôle two centuries earlier?

134 There may however be an inscription with important information on Vat Phu from a site $200 \mathrm{~km}$ to the West (or WSW). For it has been ingeniously and plausibly suggested by Ian Lowman that an attempt was made in the eleventh century to claim that the Siva of Vat Phu had shifted to the Sikhariśvara temple of Preah Vihear. In K. 380, lines $58 \mathrm{ff}$, inscribed on the Eastern doorjamb in 960 śaka (1038 AD), relate that Süryavarman I, by the power of his asceticism (tapovirya) contrived that the god Bhadreśvara of Lingapura manifest himself and rule in the Sikharīśvara temple, and required that all those belonging to the àsramas (presumably the residential religious foundations attached to the Bhadreśvara of Lingapura) declare their loyalty or devotion (bhakti) to Sikhariśvara. Cœdès, who edited the inscription (IC VI, p. 256), does not take the Bhadreśvara of Lingapura to refer to Vat Phu, observing "ces deux noms [scil. Bhadreśvara \& Lingapura] ont été portés par plusieurs localités et sanctuaires distincts, ce qui rend fort malaisé de déterminer quel est le dieu particulier dont le culte fut restauré au Práh Vihār par Sūryavarman Ier«. Lowman, however, does (Lowman, Understanding Vat Phu):

I do not think this means that Preah Vihear replaced Vat Phu or that Vat Phu ceased for a time to be an operating shrine. What it does suggest is that kings had the power to reorder the kingdom's sacred hierarchy (in this case making K. J. Śrī Sikhariśvara the kingdom's sacred centre) and to break up pre-existing tax-exempt networks, especially those which placed major constraints on royal revenue or which empowered the king's political rivals. 
In fact for many ancient sites, we tend to have just one foundation inscription, which means that we do not clearly see a before and an after. ${ }^{135}$ Having such temporally isolated datapoints means that it is very difficult to judge whether the gradual enrichment of religious institutions such as temples and medieval shospitals‘, to the supposed detriment of the king and of court circles, was not in fact an enrichment of infrastructure that strengthened much of the rest of society, spreading literacy, shared cultural values and administrative technology. In other words, rather than a scenario in which reckless royal generosity brought the kingdom to its knees, the distinctive Hindu-Buddhist civilisation of >Angkor might rather have been a victim of its own success: for we could equally postulate that a period of frenetic growth brought about demographic pressure that in turn created a nexus of environmental problems that, when compounded by a thirteenth-century climate swing and pressures from neighbouring regions, caused the collapse of the old order.

As historians, we are of course inevitably affected in such judgments by the political situations in which we find ourselves. James Heitzman, whose book-title "Gifts of Power « we have borrowed for this comparative paper, introduces his work with an illuminating sketch ${ }^{136}$ of the conflicting twentieth-century historiographical models for the early medieval history of the Tamil-speaking South of India - showing that it has been variously seen as a region centralized under the despotic authority of a king; as a region under increasingly fragmented rule after the breakdown of the Mauryan empire because of the progressive alienation of rights and taxes through grants of land and immunities; and lastly as a patchwork of long autonomous sub-regions symbolically united in a "ritual polity « under the figurehead of a king. As he winds down to a conclusion, he observes: ${ }^{137}$

Although I have personally contributed to these debates, I must admit to an increasing disinterest in them, primarily because they have become historical oddities in their own right, embedded within the intellectual and political realities of twentiethcentury south Asia.

In the end, this sort of riddle can probably never be solved. Some will choose to focus upon the vast magnificently decorated temples and the absurd grandeur of the royal eulogies, and they will set all this opulence against the paucity of evidence about how the rest of the population lived - other than evidence in the form of the interminable lists of male, female and child slaves inscribed on doorjambs and stelae - and such scholars will in consequence conjure up an image of megalomaniac kings who enslaved many of their countrymen to alien Hindu gods, erecting lavish temples that really served their own vanity, squabbling for

135 Vat Phu is in fact well documented compared to most other Khmer religious foundations, since we not only have numerous references to it in inscriptions from other sites, as mentioned above, but we also actually have a few other very early inscriptions, of the fifth and seventh centuries, from the site itself, but they are either unpublished or have little obvious bearing on finance or administration. One of the seventh-century inscriptions that I intend soon to publish, however, namely K. 1059, records that Jayavarman I appointed the son of a favourite of Bhavavarman II as lingapurasvāmī, which I believe means >Governor of Lingapurar. It therefore informs us, I think, that the enjoyment of the revenue of the town was in the seventh century a benefice that the king could bestow upon a favourite. Proving that this is a likely interpretation, however, would require a demonstration of several pages, involving quoting both unpublished inscriptions (K. 1060, K. 1235) and a handful of published ones (K. 725, K. 9), a couple of which have, I believe, been misinterpreted (K. 604, K. 1150). Such a demonstration will have to be given elsewhere.

136 Heitzman, Gifts of Power, $11 \mathrm{ff}$.

137 Heitzman, Gifts of Power, 18. 
succession with bloody military campaigns, until they finally depleted the wealth of their kingdom to the point of exhaustion. Others will prefer to focus instead upon the allusions to libraries, to provisions for education, ${ }^{138}$ to the honours accorded to specialists of religious literature, philosophy, Sanskrit grammar and astronomy, to the settlements of obscure legal disputes, and they will point to the remarkably erudite and literary character of the texts that were composed for engraving. Such scholars will see instead a flourishing of high forms of art that could surely only have been possible in a context in which the considerable surplus wealth of the region was being used to benefit more than just a narrow aristocracy. No doubt the elusive truth is somewhere in between.

\section{III: Concluding remarks}

Over two decades have passed since Bijsterveld noted that there was scope to compare historical texts dealing with gift-giving in medieval Europe with their counterparts in Asia. In those two decades, there has been an exponential growth in global and comparative history, contrasting such diverse and distant phenomena as, for instance, the tenth-century feudal revolution in Europe and the transformation in China (where half a century of continuous warfare and fierce political struggles led to the remarkable rise of a new society reflected in the Song civilization and economy). But it remains the case that there have been relatively few attempts to make detailed text-based comparisons between western and eastern societies during the medieval epochs. Comparisons by historians have tended towards juxtaposing different regions within Europe or East Asia, often with an emphasis upon connections with states with comparable constitutions and societies with similar social orders. ${ }^{139}$

Other than the inherent difficulty in mastering all the requisite languages for comparisons that reach further afield, many historiographical factors explain this state of affairs. To highlight just one, many models of commerce, exchange and gift-giving in a comparative framework start off from a European perspective, with the result that it is hard to avoid an intellectual argument which uses detailed knowledge of the organisation of western societies to illuminate eastern societies, and this can make it difficult to pay as much attention to key Asian primary sources as their western counterparts in making historical arguments. ${ }^{140}$ This problem is compounded by the relative paucity of scholarship on certain areas of, for instance, South East Asian history.

Both among the Anglo-Saxons and among the Khmers, royal edicts that proclaim rich gifts and immunities to religious foundations often suggest to us at first blush a larger political or economic narrative, about, for instance, a weakening of the state in favour of religious institutions. But in both cases our sources are patchy and can only show us a tiny part of the picture. For the cases we have examined, we therefore feel a great deal less certain about such

138 The numerous so-called hospitak-stelae, for instance, all issued in 889 by King Yaśovarman, provide plentiful allusions to provisions made for fostering learning (K. 12, K. 209, K. 368, K. 375, K. 386, K. 387, K. 395, K. 402, K. 435, K. 537, K. 602, K. 614, K. 667, K. 952, K. 955, K. 1115 and K. 1170). Also the digraphic shospitals-stelae (K. 42, K. 45, K. 47, K. 57, K. 95, K. 101, K. 110, K. 223, K. 309, K. 323, K. 346, K. 362, K. 479, K. 1005, K. 1092, K. 1093 , K. 1223; and, in Angkor, K. 279, K. 290, and K. 701).

139 For recent examples of comparative studies of states in England with their counterparts in western Europe during the ninth and tenth centuries, see Bassett, Divide and Rule?, 84-85; Molyneux, Formation of the English Kingdom.

140 For critiques of western-orientated perspectives, see, Carrier, Maussian Occidentalism; Kuper, Invention of Primitive Society, 3-112. 
narratives, which one might have hoped to see confirmed (or else weakened) by our comparisons. What we think we can establish is that royal grants made to religious foundations in distant Asia do indeed furnish striking parallels to those in midland England, despite the obvious differences in these societies and indeed the precise nature of the grants. And we therefore ask ourselves: can it really be no more than coincidence that state-formation in far-flung parts of the world, so far distant that no direct mutual influence can be supposed, should pass through a phase of development characterized by the concentration of resources in centres of organized religion as a result of royal patronage?

We are thus to some degree attracted to Victor Lieberman's attempt to show how such Strange Parallels might be the result of parallel structures and parallel large-scale changes in climate and economy. Lieberman has suggested that in both Europe and Asia between the ninth and the seventeenth centuries, rulers and elites established their authority over regions of comparable scale with broadly similar social and economic conditions ${ }^{141}$ His observations encouraged us to attempt to juxtapose Anglo-Saxon charters and Khmer inscriptions. So although we have no grand conclusions to draw (partly because our evidence in the individual cases we adduce is so sparse and its interpretation often uncertain), we feel that it is clear that the parallelism is real, that there may be shared political and social patterns that might one day emerge more clearly, and that further investigation of such parallels might eventually enable us better to account for them. Just as in textual-criticism, the dispassionate juxtaposition of many parallels can illuminate many a knotty passage of text, so too, the larger canvas of the history of religious immunities in one part of the world may receive light from a detailed and unbiased juxtaposition of those in others.

\section{Appendix: authority of two Anglo-Saxon charters}

Hanbury: The charter which recorded Abbot Ceolfrith's grant of 20 hides, c. $757 \times 774$, to the bishop of Worcester was viewed by Finberg as referring to Henbury (Gloucs.), but as Orme has shown, there are reasons for doubting this view. ${ }^{142}$ First, the place-name Heanburg can as plausibly be rendered as Hanbury; second, the charter was copied into the Worcestershire element of the Liber Wigorniensis; and third, the second place mentioned in the grant, Ismere, is to be identified with Sture at Kidderminster, also in north-west Worcestershire and the site of an important early minster.

Westbury: Wormald argued that the charter which recorded Offa's grant of 60 hides at Westbury to the bishopric of Worcester c. $793 \times 796$ was a Worcester forgery, drawn up in the context of a subsequent dispute between the kin of Æthelmund and the bishopric of Worcester on the one hand and Berkeley minster on the other hand over the control of the lands and minster at Westbury in the first quarter of the ninth century. The forgery designed to give Worcester an unimpeachable claim that was recognized at the council of Clofesho in 826, with the result that Offa's charter c. $793 \times 796$ in favour of Æthelmund, granting him 55 hides at Westbury, should be regarded as the authentic text for understanding events in those years. ${ }^{143}$ The case for viewing the charter in favour of Worcester as a forgery rests, first, on the fact that it omits Hygeberht, the newly appointed archbishop of Lichfield, from the witness list in contrast to his inclusion in the witness list in the charter in favour of Æthelmund;

141 Lieberman, Strange Parallels, Vol. 2, 1-122.

142 S 1411 (B 220); Orme and Canon, Westbury-on-Trym, 5.

143 Wormald, How Do we Know, 20-22; S 146 (B 272); S 1433 B 379); S 139 (B 274). 
and second, that the Canterbury scriptorium in the early ninth century was forging charters to establish their control over the Kentish minsters, so it is at least not inconceivable, and is perhaps not unlikely, that Worcester pursued the same objectives by the same means ${ }^{144}$ But there are reasons for doubting this view. First, both charters were copied into the Liber Wigorniensis and hence were regarded as informative and valued texts from a historical perspective by Worcester; second, if the charter in favour of Worcester was forged in the early ninth century, it needs to be assumed that it was plausible at that moment to concoct a charter which pointed to tension between Æthelmund and Worcester, when both a charter of 770 and the settlement of a dispute in 824 indicate continuing friendship between Æthelmund and his kin with the bishop and monastic community of Worcester. ${ }^{145}$ The parallel with the activities of the Canterbury scriptorium seems attractive, but on closer inspection requires further consideration. Offa and his successor Ceonwulf made a consistent, continuous and concerted effort to exercise control over the royal minsters founded by the Kentish royal house bringing the Mercian kings into conflict with successive archbishops of Canterbury during the late eighth and early ninth centuries, ${ }^{146}$ but with the possible exception of Ceonwulf's relationship with Winchombe minster (Gloucs.) there is little evidence to suggest a parallel policy within the Hwiccian kingdom. ${ }^{147}$

\section{Acknowledgements}

We are grateful to Charles West, the participants of the >Religious immunities and the stater conference, and Elisabeth Wareham for discussion and assistance; and to Robert Gallagher and Gudrun Gleba both for discussion and for making available a lecture text and a forthcoming article respectively.

\section{Abbreviations}

B: Cartularium Saxonicum: Collection of Charters Relating to Anglo-Saxon History, vols. 1-2, ed. Walter de Gray Birch (London, 1885-1887).

BL: British Library.

IC: (vols. 1-8). See George Cœedès, Inscriptions du Cambodge.

PASE: Prosopography of Anglo-Saxon England. Retrieved on 27 November 2017: http:// www.pase.ac.uk.

S: Electronic Sawyer. Retrieved on 27 November 2017:http://www.esawyer.org.uk/about/ index.html.

\footnotetext{
144 Wormald, How Do we Know, 22.

145 S 59 (B 203); S 1433 (B 379).

146 Brooks, Early History, 129-154.

147 Bassett, Probable Mercian Royal Mausoleum; idem, Search of the Origins, 8; cf. Levison, England and the Continent, 249-259.
} 


\section{References}

Algazi, Gadi, Groebner, Valentin and Jusse, Bernhard (eds.), Negotiating the Gift: Pre-Modern Figures of Exchange (Gottingen, 2003).

Barth, Auguste, Stèle de Vat Phou près de Bassac (Laos), Bulletin de l'École française d'ExtrêmeOrient 2 (1902) 235-240.

Bassett, Steven, A Probable Mercian Royal Mausoleum at Winchcombe, Gloucestershire, Antiquaries Journal 65 (1985) 82-100.

Bassett, Steven, In Search of the Origins of Anglo-Saxon Kingdoms, in: idem (ed.), The Origins of Anglo-Saxon Kingdoms (London, 1989) 3-27.

Bassett, Steven, Divide and Rule? The Military Infrastructure of Eighth- and Ninth-Century Mercia, Early Medieval Europe 15 (2007) 53-85.

Bassett, Steven, The Landed Endowment of the Anglo-Saxon Minster at Hanbury (Worcs.), Anglo-Saxon England 39 (2008) 77-100.

Baxter, Stephen, Archbishop Wulfstan and the Administration of God's Property, in: Matthew Townend (ed.), Wulfstan, Archbishop of York: The Proceedings of the Second Alcuin Conference (Turnhout, 1984) 161-205.

Bede, The Ecclesiastical History of the English People, ed. and trans. Judith McClure and Roger Collins (Oxford, 1994).

Bergaigne, Abel, Notices et extraits des manuscrits de la Bibliothèque nationale et autres bibliothèques publiés par l'Institut national de France. Faisant suite aux notices et extraits lus au comité établi dans l'Académie des inscriptions et belles-lettres, Tome vingt-septième ( $1^{\mathrm{re}}$ partie), $2^{\mathrm{e}}$ fascicule (Paris, 1893).

Bijsterveld, Arnoud-Jan, The Medieval Gift as Agent of Social Bonding and Political Power: A Comparative Approach, in: Esther Cohen and Mayke B. de Jong, ed., Medieval Transformations: Texts, Power, and Gifts in Context, Cultures, Beliefs and Traditions: Medieval and Early Modern Peoples 11 (Leiden, 2001) 123-156; a revised version also in: Arnoud-Jan Bijsterveld (ed.), Do ut des. Gift Giving, Memoria, and Conflict Management in the Medieval Low Countries, Middeleeuwse Studies en Bronnen 104 (Hilversum, 2007) 17-39.

Blair, John, The Church in Anglo-Saxon Society (Oxford, 2005).

Brooks, Nicholas, The Early History of the Church of Canterbury. Christ Church from 597 to 1066 (London, 1984).

Brooks, Nicholas, The Formation of the Mercian Kingdom, in: Steven Bassett (ed.), The Origins of Anglo-Saxon Kingdoms (London, 1989) 159-170.

Brooks, Nicholas, The Development of Military Obligations in Eighth- and Ninth-Century England, in: idem, Communities and Warfare, 700-1400 (London, 2000) 32-47.

Campbell, James, Bede's Reges and Principes, in: idem, Essays in Anglo-Saxon History (London, 1986) 85-98.

Campbell, James, The Sale of Land and the Economics of Power in Early England: Problems and Possibilities in: idem, The Anglo-Saxon State (London, 2000) 227-246.

Carrier, James, Maussian Occidentalism: Gift and Commodity Systems, in: idem, (ed.), Occidentalism: Images of the West (Oxford, 1995) 85-108.

Chadwick, Hector Munro, Studies on Anglo-Saxon Institutions (Cambridge, 1905).

Clarke, Howard, Economy, in: Pauline Stafford (ed.), A Companion to the Early Middle Ages: Britain and Ireland, c. 500-c. 1100 (Oxford, 2009) 57-75.

Coates, Richard, The Name of the Hwicce: A Discussion, Anglo-Saxon England 42 (2013) 5161. 
Cœdès, George, La stèle du Ta-Prohm, Bulletin de l'École française d'Extrême-Orient 6 (1906) 44-81.

Cœdès, George, La stèle du Práḥ Khăn d'Anikor, Bulletin de l'École française d'Extrême-Orient 41 (1941) 255-302.

Cœdès, George, Inscriptions du Cambodge [IC], 8 vols. (Hanoi and Paris, 1937-1966).

Cox, David, The Church and Vale of Evesham 700-1215: Lordship, Landscape, and Prayer (Woodbridge, 2015).

Cribb, Joe, First Coin of Ancient Khmer Kingdom Discovered, Numismatique Asiatique 6 (2013) 9-16.

Cubitt, Catherine, Anglo-Saxon Church Councils c. 650-c. 850 (London, 1995).

Curta, Florin, Merovingian and Carolingian Gift Giving, Speculum 81 (2006) 671-699.

Davies, Wendy and Paul Fouracre (eds.), The Languages of the Gift in the Early Middle Ages (Cambridge, 2010).

Domesday Book Worcestershire, ed. and trans. Frank and Caroline Thorn (Chichester, 1982).

Dugdale, William, Monasticon Anglicanum (new edition) 6 vols. (London, 1817-1830).

Dyer, Christopher, Lords and Peasants in a Changing Society: The Estates of the Bishopric of Worcester, 680-1540 (Cambridge, 1980).

Dyer, Christopher, Hanbury: Settlement and Society in a Wooded Landscape, Department of English Local History Occasional Paper 4th ser., 4 (Leicester, 1991).

Estève, Julia and Soutif, Dominique, Les Yaśodharāśrama, marqueurs d'empire et bornes sacrées. Conformité et spécificité des stèles digraphiques khmères de la région de Vat Phu, Bulletin de l'École française d'Extrême-Orient 97-98 (2010-2011) 331-355.

Faith, Rosamond, The English Peasantry and the Growth of Lordship (London, 1997).

Faith, Rosamond, The Structure of the Market in Early Medieval Lincolnshire, Economic History Review 65 (2012) 674-700.

Finot, Louis, Notes d'épigraphie XIII. L'inscription de Ban That, Bulletin de l'École française d'Extrême-Orient 12 (1912) 1-28.

Finot, Louis, Inscriptions d'Anikor, Bulletin de l'École française d'Extrême-Orient 25 (1925), 289-407.

Gallagher, Robert, Vernacular in Anglo-Saxon Charters: Expansion and Innovation in NinthCentury England, Historical Research (forthcoming).

Gleba, Gudrun, Was kostet das Seelenheil? Gibt es eine Einheitsgebühr oder einen Individualtarif? Vortrag in der katholischen Akademie »Wolfburg«, Mülheim an der Ruhr, 11. November 2007 [What is the price of spiritual salvation. Is there a standard fee or an individual tariff? Public lecture at the Wolfsburg Catholic Academy, Mülheim].

Goodall, Dominic and Isaacson, Harunaga, The Raghupañcikà of Vallabhadeva, Being the Earliest Commentary on the Raghuvamiśa of Kälidàsa, Vol. 1: Critical edition with introduction and notes (Groningen, 2003).

Goodall, Dominic and Jacques, Claude, Stèle inscrite d'Íśānavarman II à Vat Phu : K. 1320, Aséanie 33 (2014, appeared 2016) 395-454.

Gurevich, Aron, Categories of Medieval Culture, trans. G. L. Campbell (London, 1985).

Hawixbrock, Christine, La stèle inscrite K. 1320. Note sur une nouvelle découverte archéologique à Vat Phu, Aséanie 30 (2012, appeared 2013) 103-119.

Heitzman, James, Gifts of Power: Lordship in an Early Indian State (Calcutta, Chennai and Mumbai, 1997).

Higham, Nicholas and Ryan, Martin, The Anglo-Saxon World (New Haven and London, 2013). Hooke, Della, The Anglo-Saxon Landscape: The Kingdom of the Hwicce (Manchester, 1985). 
Hooke, Della, Worcestershire Anglo-Saxon Charter Bounds (Woodbridge, 1990).

Hooke, Della, The Droitwich Salt Industry: An Examination of the West Midland Charter Evidence, Anglo-Saxon Studies in Archaeology and History 92 (1991) 123-169.

James, Edward, The Origins of the Barbarian Kingdoms: The Continental Evidence, in: Steven Bassett (ed.), The Origins of Anglo-Saxon Kingdoms (London) 40-52.

Jones, Stephen Richard Henry, Transaction Costs, Institutional Change, and the Emergence of a Market Economy in Later Anglo-Saxon England, Economic History Review 46 (1993) 658-678.

Kelly, Susan, Offa (d. 796), King of the Mercians, in: Laurence Goldman (ed.), Oxford Dictionary of National Biography 41 (Oxford, 2005) 545-548.

Kelly, Susan (ed.), Charters of Peterborough Abbey, Anglo-Saxon Charters XIV (London, 2009)

Keynes, Simon, Mercia and Wessex in the Ninth Century, in: Michelle Brown and Carol Farr (eds.), Mercia: An Anglo-Saxon Kingdom in Europe (London, 2001) 310-328.

Keynes, Simon, The West Saxon Charters of King Æthelwulf and his Sons, English Historical Review 109 (1994) 1109-1149.

Keynes, Simon, England, 700-900, in: Rosamund McKitterick (ed.), New Cambridge Medieval History, vol. II (Cambridge, 1995) 18-42.

King, Vanessa, St Oswald's tenants, in: Nicholas Brooks and Catherine Cubitt (ed.), St Oswald of Worcester: Life and Influence (London, 1996) 100-116.

King, Vanessa, From Minster to Manor: the Early History of Bredon, in: David Roffe (ed.), The English and their Legacy. Essays in Honour of Ann Williams (Woodbridge, 2012) 79-93.

Kuper, Adam, The Invention of Primitive Society: Transformation of an Illusion (London, 1986). Latouche, Robert, Les Origines des l'Economie Occidentale (Paris, 1956) [with quotation from the English edition: The Birth of the Western Economy: Economic Aspects of the Dark Ages, trans. Ethel Marjorie Wilkinson (London, 1961)].

Levison, Wilhelm, England and the Continent in the Eighth Century (Oxford, 1946).

Lieberman, Victor, Strange Parallels. Southeast Asia in Global Context, c. 800-1830, Vol. 1: Integration on the Mainland (Cambridge, 2003).

Lieberman, Victor, Strange Parallels: Southeast Asia in Global Context, c. 80o-1830. Vol. 2: Mainland Mirrors: Europe, Japan, China, South Asia, and the Islands (Cambridge, 2009).

Lorillard, Michel, Autour de Vat Phu, de l'exploration à la recherché (1866-1957) (Vientiane, 2012).

Lowman, Ian, Understanding Vat Phu: An Early Khmer Pilgrimage Site (unpublished talk delivered at the workshop Trans-Border Archaeologies: Vat Phu and Angkor, December 15, 2015).

McKinley, Allan, Understanding the Earliest Bishops of Worcester c. 660-860, in: Alexander Rumble (ed.), Leaders of the Anglo-Saxon Church from Bede to Stigand (Woodbridge, 2012), 97-107.

Molyneux, George, The Formation of the English Kingdom in the Tenth Century (Oxford, 2015)

Naismith, Rory, Money and Power in Anglo-Saxon England: The Southern Kingdoms, 757-865 (Cambridge, 2012).

Naismith, Rory, Payments for Land and Privilege in Anglo-Saxon England, Anglo-Saxon England 41 (2012) 277-342.

Naismith, Rory, The Land Market in Anglo-Saxon Society, Historical Research 89 (2016) 1941. 
Nelson, Janet, The Settings of the Gift in the Reign of Charlemagne, in: Wendy Davies and Paul Fouracre (eds.), The Languages of the Gift in the Early Middle Ages (Cambridge, 2010), 116-148.

Nennius, The Historia Brittonum: British History and Welsh Annals, ed. and trans. John Morris (Chichester, 1980).

Orme, Nicholas and Jon Cannon, Westbury-on-Trym: Monastery, Minster and College (Bristol, 2010).

Pelliot, Paul, Le Fou-nan, Bulletin de l'École française d'Extrême-Orient 3 (1903) 248-303.

Pelliot, Paul, Mémoires sur les coutumes du Cambodge de Tcheou Ta-Kouan (Paris, 1951).

Pollock, Sheldon, The Language of the Gods in the World of Men: Sanskrit, Culture and Power in Premodern India (Berkeley, 2006).

Quigley, Declan, Introduction. The Character of Kingship, in: idem (ed.), The Character of Kingship (Oxford, 2005) 1-24.

Reuter, Timothy, Property Transactions and Social Relations between Rulers, Bishops and Nobles in Early Eleventh-Century Saxony: The Evidence of the Vita Meinwerci, in: Wendy Davies and Paul Fouracre (eds.), Property and Power in the Early Middle Ages (Cambridge, 1995) 165-199.

Reynolds, Andrew, Early Medieval Period, Bristol and Gloucestershire Archaeological Report 11 (2014) 133-160. Retrieved on 27 November 2017: http://www.cotswoldarchaeology. co.uk/content/uploads/2014/11/Bristol-Gloucestershire-Archaeological-Report-No.-3r_ part-4.pdf.

Roncaglia, Alessandro, The Wealth of Ideas: A History of Economic Thought (Cambridge, 2006).

Rosenwein, Barbara, Negotiating Space: Power, Restraint, and Privileges of Immunity in Early Medieval Europe (Ithaca, 1999).

Rosenwein, Barbara, Francia and Polynesia: Rethinking Anthropological Approaches, in: Gadi Algazi, Valentin Groebner and Bernhard Jusse (eds.), Negotiating the Gift: Pre-Modern Figures of Exchange (Gottingen, 2003) 361-379.

Sahai, Sachchidanand, Les institutions politiques et l'organisation administrative du Cambodge ancien (Ve-XIIIe siècles) (Paris, 1970).

Samson, Ross, Economic Anthropology and the Vikings, in: idem (ed.), Social Approaches to Viking Studies (Glasgow, 1991).

Schnepel, Burkhard, Kings and Tribes in East India: The Internal Political Dimension, in: Declan Quigley (ed.), The Character of Kingship (Oxford, 2005) 187-207.

Sims-Williams, Patrick, Religion and Literature in Western England, 600-800 (Cambridge, 1990).

Snook, Ben, When Aldhelm Met the Vikings: Advanced Latinity in Ninth-Century Mercian Charters, Mediaevistik 26 (2013) 111-148.

Soutif, Dominique, Organisation religieuse et profane du temple khmer du VIIe au XIIIe siècle, Unpublished PhD thesis (Sorbonne University, 2009).

Tinti, Francesca, Sustaining Belief: The Church of Worcester from c. 870 to c. 1100 (Farnham, 2010).

Vickery, Michael, Society, Economics, and Politics in Pre-Angkor Cambodia, the 7th-8th Centuries (Tokyo, 1998).

Wareham, Andrew, St Oswald's Family and Kin, in: Nicholas Brooks and Catherine Cubitt (ed.), St Oswald of Worcester: Life and Influence (London, 1996) 46-63.

Wareham, Andrew, The Redaction of Cartularies and Economic Upheaval in Western England c. 996-1096, in: David Bates (ed.), Anglo-Norman Studies 36 (2013) 189-219. 
Weiner, Annette, Inalienable Possessions: The Paradox of Keeping-While-Giving (Berkeley and Los Angeles, 1992).

White, Stephen, The Politics of Exchange: Gifts, Fiefs and Feudalism, in: Gadi Algazi, Valentin Groebner and Bernhard Jusse (eds.), Negotiating the Gift: Pre-modern Figures of Exchange (Gottingen, 2003) 169-88.

Whitelock, Dorothy (ed. and trans.), English Historical Documents I, c. 500-1042 (2nd edition), (London, 1979).

Wormald, Patrick, The Ninth Century, in: James Campbell (ed.), The Anglo-Saxons (Oxford, 1982) 132-157.

Wormald, Patrick, How Do we Know so much about Anglo-Saxon Deerhurst, Deerhurst Lecture 1991 (Deerhurst, 1993)

Wright, David, From War to Diplomatic Parity in Eleventh-Century China: Sung's Foreign Relations with the Kitan Liao (Leiden, 2005).

Yorke, Barbara, Kings and Kingdoms of Early Anglo-Saxon England (London, 1990).

Yorke, Barbara, Nunneries and Anglo-Saxon Royal Houses (London, 2003).

Zaluckyj, Sarah, Mercia: The Anglo-Saxon Kingdom of Central England (Logaston, 2001).

\section{Manuscripts}

BL Augustus ii. 9 manuscript.

BL Cotton Tiberius A.xiii manuscript. 